Florida International University FIU Digital Commons

\title{
The Stability of Uranium-Bearing Precipitates Created as a Result of Ammonia Gas Injections in the Hanford Site Vadose Zone
}

Alberto Javier Abarca Betancourt

aabar003@fiu.edu

DOI: 10.25148 /etd.FIDC001917

Follow this and additional works at: https://digitalcommons.fiu.edu/etd

Part of the Environmental Engineering Commons

\section{Recommended Citation}

Abarca Betancourt, Alberto Javier, "The Stability of Uranium-Bearing Precipitates Created as a Result of Ammonia Gas Injections in the Hanford Site Vadose Zone" (2017). FIU Electronic Theses and Dissertations. 3359.

https://digitalcommons.fiu.edu/etd/3359 


\section{FLORIDA INTERNATIONAL UNIVERSITY}

Miami, Florida

\section{THE STABILITY OF URANIUM-BEARING PRECIPITATES CREATED AS A RESULT OF AMMONIA GAS INJECTIONS IN THE HANFORD SITE VADOSE ZONE}

A thesis submitted in partial fulfillment of the

requirements for the degree of MASTER OF SCIENCE

in

ENVIRONMENTAL ENGINEERING

by

Alberto Javier Abarca Betancourt 
To: Interim Dean Ranu Jung

College of Engineering and Computing

This thesis, written by Alberto Javier Abarca Betancourt, and entitled The Stability of Uranium-Bearing Precipitates Created as a Result of Ammonia Gas Injections in the Hanford Site Vadose Zone, having been approved in respect to style and intellectual content, is referred to you for judgment.

We have read this thesis and recommend that it be approved.

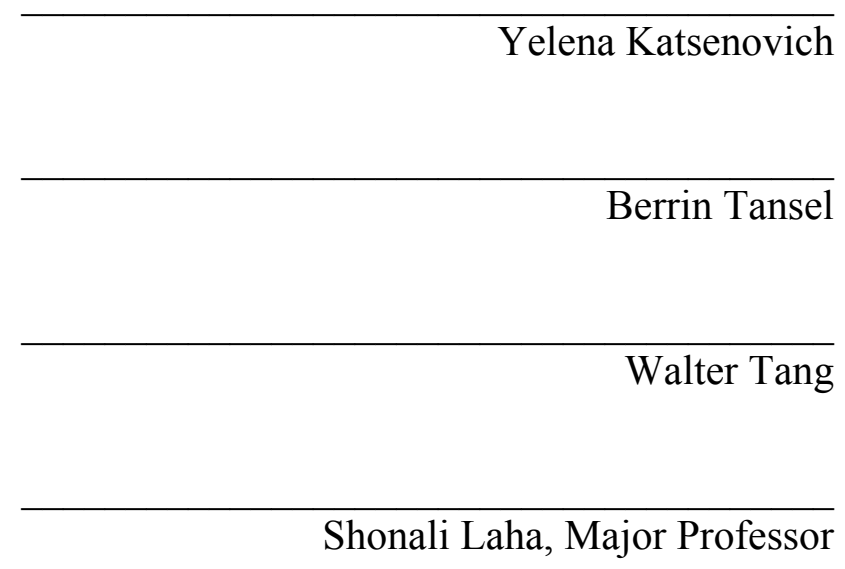

Date of Defense: June 26, 2017

The thesis of Alberto Javier Abarca Betancourt is approved.

Interim Dean Ranu Jung

College of Engineering and Computing

Andrés G. Gil

Vice President for Research and Economic Development

and Dean of the University Graduate School

Florida International University, 2017 


\section{DEDICATION}

I dedicate this effort to my parents, close family members and beloved ones, who have always supported me and believed in my capabilities. I also dedicate this thesis to the Department of Energy, Florida International University Science and Technology Workforce Development Program along with its staff, mentors and fellows. Thanks for providing me the opportunity to fulfill my education goals. 


\section{ACKNOWLEDGMENTS}

I wish to thank the members of my committee: Dr. Shonali Laha, for being more than a professor: a mentor who guided me throughout my graduate education in many professional and human aspects since the very beginning of this journey when I first arrived at this country. Dr. Yelena Katsenovich, for giving me the opportunity to join the Applied Research Center (ARC), contributing to her research and mentoring me to develop invaluable educational and professional skills. I am also thankful to Dr. Berrin Tansel and Dr. Walter Tang, for their service and recommendations towards completing my degree with excellence. In addition, I desire to express my appreciation to all the Department of Civil and Environmental Engineering and ARC Staff, Professors and Students who contributed to this project. Finally, I would like to sincerely thank the DOE-FIU Science and Technology Workforce Development Program Director for supporting me throughout this investigation. Funding for this research was provided by US DOE Grant Number: Under Cooperative Agreement No. DE-EM0000598. 
ABSTRACT OF THE THESIS

THE STABILITY OF URANIUM-BEARING PRECIPITATES CREATED AS A

RESULT OF AMMONIA GAS INJECTIONS IN THE HANFORD SITE VADOSE

ZONE

by

Alberto Javier Abarca Betancourt

Florida International University, 2017

Miami, Florida

Professor Shonali Laha, Major Professor

Uranium (U) is a crucial contaminant in the Hanford Site. Remediation techniques to prevent contaminant migration of $\mathrm{U}$ located in the soils to other important water resources such as the Columbia River are of paramount importance. Given the location of the contaminant in the deep vadose zone, sequestration of $\mathrm{U}$ caused by ammonia $\left(\mathrm{NH}_{3}\right)$ gas injections appears to be a feasible method to decrease $\mathrm{U}$ mobility in the contaminated subsurface via $\mathrm{pH}$ manipulation, ultimately converting aqueous $\mathrm{U}$ mobile phases to lower solubility precipitates that are stable in the natural environment. This study evaluated the stability of those U-bearing precipitates via preparation of artificial precipitates mimicking those that would be created after $\mathrm{NH}_{3}$ gas injections and sequential extractions experiment. Results showed that most of the $\mathrm{U}$ was recovered with the extracting solutions targeted to remove uranyl silicates and hard-to-extract $U$ phases, suggesting that $U$ present in the solid particles has strong bonds to the vadose zone sediments, causing the precipitates to be stable and therefore the remediation technology to be effective under the simulated conditions. 


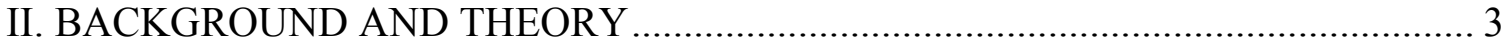

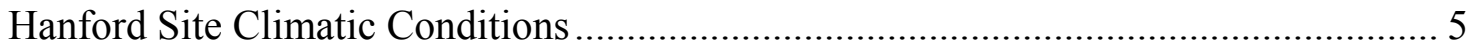

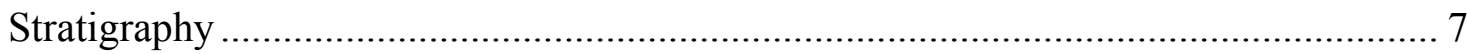

Hanford Formation Mineralogy ............................................................................ 8

Bulk Chemical Composition ..................................................................................... 10

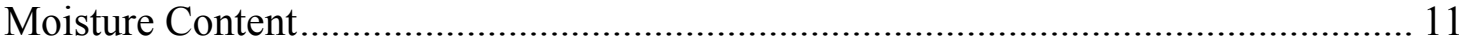

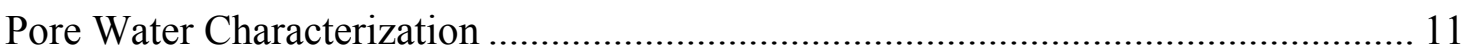

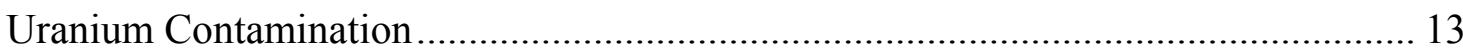

Remediation Strategy ………………………………........................................ 16

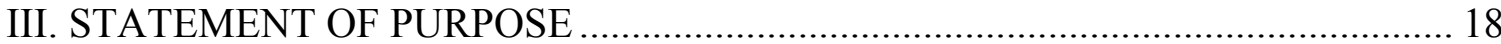

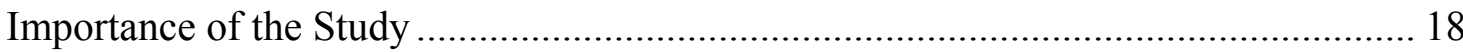

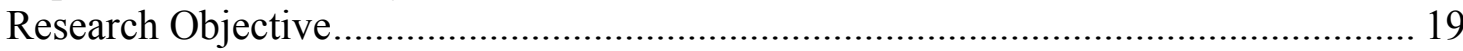

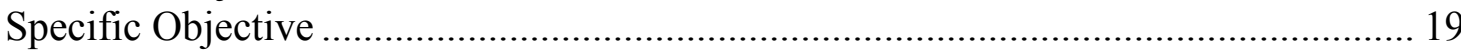

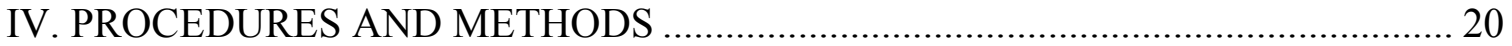

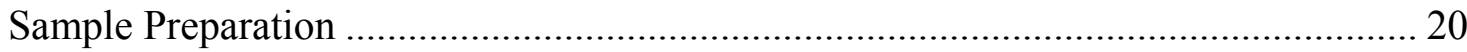

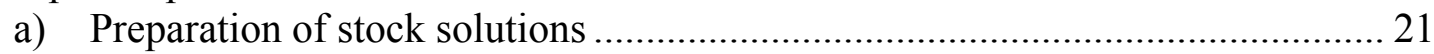

b) Preparation of samples containing U-bearing precipitates.................................. 22

Sequential Extraction Experiment........................................................................ 24

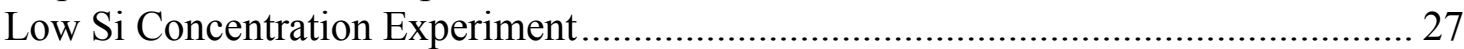

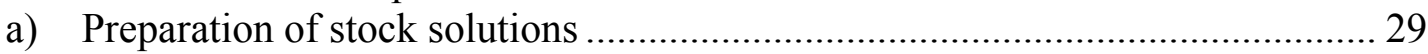

b) Preparation of U-bearing precipitates samples................................................... 30

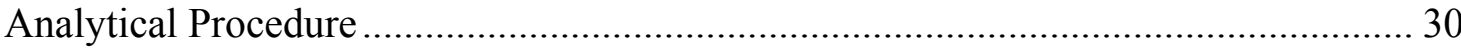

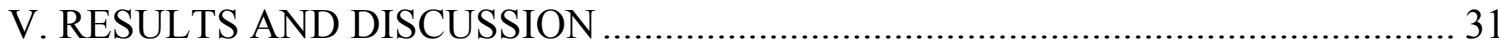

Sequential Extraction on Unfiltered Samples .............................................................. 31

Sequential Extraction on Filtered Samples .................................................................. 33

Synthetic Pore Water Optimization and Mass Balance …………………………....... 37

Low Si Concentrations Experiment ........................................................................ 40

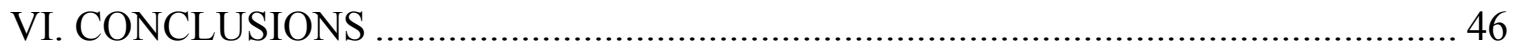

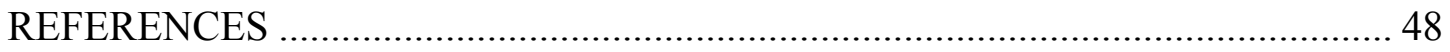




\section{LIST OF TABLES}

TABLE

PAGE

Table 1. Climate Average Conditions at the Hanford Site..............................6

Table 2: Average Calculated Cation Pore water Content for Borehole 299-E33-338....12

Table 3: Background Uranium-Sediment Concentrations............................15

Table 4: Target concentrations in synthetic pore water solutions to create U-bearing

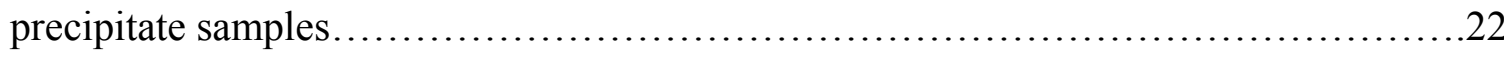

Table 5: Type and amount of salts used to prepare Stock Solutions......................22

Table 6: Amount of Stock Solution and DIW to prepare $40 \mathrm{~mL}$ of mixed sample.........24

Table 7: Amount of mixed sample, $\mathrm{Ca}$ and $\mathrm{U}$ to prepared six $10 \mathrm{~mL}$ volume containing

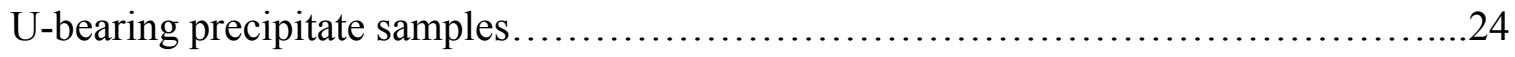

Table 8: Sequential Extraction Experiment Steps..................................26

Table 9: Target concentrations in synthetic pore water solutions to create U-bearing

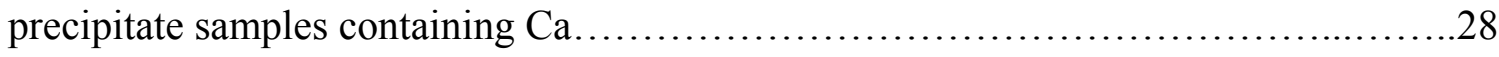

Table 10: Target concentrations in synthetic pore water solutions to create U-bearing

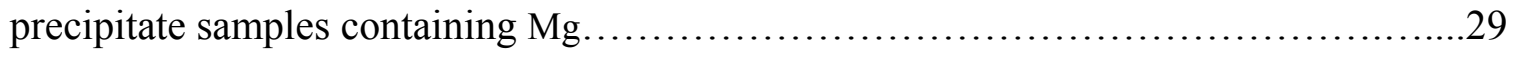

Table 11: Target concentrations in synthetic pore water solutions to create U-bearing precipitate samples containing Fe ...................................................

Table 12: Type and amount of salts used to prepare Stock Solutions for Low $\mathrm{Si}$ Concentrations Experiment. 30 


\section{LIST OF FIGURES}

FIGURE

PAGE

Figure 1: Hanford Site Area..................................................4

Figure 2: Hanford Site tank farms highlighting ARC-FIU research study areas............... 5

Figure 3: Borehole 299- E33-338 Stratigraphy in 200 East Area.................................. 7

Figure 4: Generalized West-to-East Geologic Cross Section through the Hanford Site.....8

Figure 5: Sequential Uranium Extraction of Unfiltered Sample Precipitates on Mass

Basis........................................................................

Figure 6: Uranium Extraction Distribution for unfiltered low $\mathrm{HCO}_{3}$ samples................ 32

Figure 7: Uranium Extraction Distribution for unfiltered high $\mathrm{HCO}_{3}$ samples................ 33

Figure 8: Sequential Uranium Extraction of Filtered Sample Precipitates on Mass

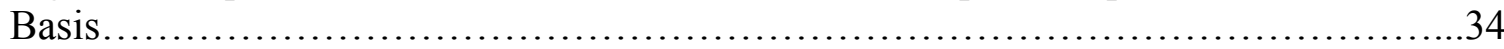

Figure 9: Uranium Extraction Distribution for filtered low $\mathrm{HCO}_{3}$ samples ................... 35

Figure 10: Uranium Extraction Distribution for filtered high $\mathrm{HCO}_{3}$ samples................. 36

Figure 11: Response surface diagrams displaying filtrate solution uranium retention in samples

Figure 12: Percent removal of $\mathrm{U}(\mathrm{VI})$ tested at variable bicarbonate and silica concentrations in $5 \mathrm{mM} \mathrm{Al}$ amended solutions containing $2 \mathrm{mg} / \mathrm{L} \mathrm{U}$ (VI) and (A)

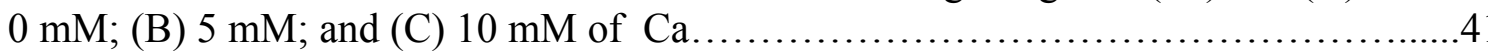

Figure 13: Percent removal of U (VI) tested at variable bicarbonate and silica concentrations in $5 \mathrm{mM} \mathrm{Al}$ amended solutions containing $2 \mathrm{mg} / \mathrm{L} \mathrm{U}$ (VI) and (A) $5 \mathrm{mM}$; and (B) $10 \mathrm{mM}$ of $\mathrm{Mg}$

Figure 14: Figure 13: Percent removal of U (VI) tested at variable bicarbonate and silica concentrations in $5 \mathrm{mM} \mathrm{Al}$ amended solutions containing $2 \mathrm{mg} / \mathrm{L} \mathrm{U}$ (VI) and (A) 0.2 $\mathrm{mM}$; and (B) $5 \mathrm{mM}$ of Fe. 


\section{INTRODUCTION}

Past nuclear weapons production and other defense related activities led to improper waste disposal and storage practices causing serious environmental contamination at Department of Energy (DOE) sites throughout the United States. Uranium (U) is the key element of the nuclear fuel cycle; during fission, major $\mathrm{U}$ isotopes are formed: ${ }^{235} \mathrm{U}$ being the fissile isotope, ${ }^{238} \mathrm{U}$ being a reactant for the formation of ${ }^{239} \mathrm{Pu}$, and others. Uranium was used in massive quantities during production years at the DOE Hanford site as follows: uranium fuels were assembled in the 300 Area, irradiated by eight nuclear reactors in the 100 Area and reprocessed to recover $\mathrm{U}$ and produce plutonium in the 200 area (Zachara et al., 2007). Furthermore, approximately $200,000 \mathrm{~kg}$ of U were discharged to the ground in the Hanford 200 and 300 areas as part of the previous and other associated waste disposal activities as well as accidental spills (Corbin et al., 2006).

A significant residual mass of uranium still resides in the deep vadose zone (VZ) where oxidizing, carbonate-rich, neutral to mildly basic subsurface conditions prevail. This contamination has caused the creation of three groundwater plumes with a combined area of 1.6 square kilometers with dissolved U (VI) concentrations above the Environmental Protection Agency (EPA)-established Maximum Contaminant Level (MCL) of $30 \mathrm{ppb}$ (Hartman, 2007). Additionally, there is evidence that certain groundwater U(VI) plumes continue to grow in size indicating a sustained flux from the vadose zone (Hartman, 2007). Uranium contamination of soil and groundwater is of great environmental concern due to the toxicological properties of the uranyl species. The Columbia River, which serves as the main source of water supply for nearby populations, is transverse through the Hanford site 
areas, and large scale remediation efforts have been undertaken to treat uranium wastes released to soil and groundwater to prevent the movement of contaminated plumes into the river. Additionally, according to Zachara et al., (2007), an ominously larger number of vadose zone plumes of $U$ exist below cribs, trenches and retention basins that have not yet migrated to groundwater. The biggest concern exists over their future migration to the very highly permeable saturated zone and knowledge on new remediation technologies are sought to mitigate the migration behavior of $U(V I)$ plumes .

Remediation of this type of contamination located in the Hanford Site VZ is a challenging task due to the depth of contaminants in combination with the predominant uranylcarbonate complexes $\left(\mathrm{UO}_{2} \mathrm{CO}_{3}{ }^{0}, \mathrm{UO}_{2}\left(\mathrm{CO}_{3}\right)_{2}{ }^{2-}\right.$ and $\left.\mathrm{UO}_{2}\left(\mathrm{CO}_{3}\right)_{3}{ }^{4-}\right)$ characterized by high mobility, ultimately creating a potential source of contamination for the underlying aquifer. Therefore, in-situ remediation methods require sequestration of uranium in the subsurface to prevent further spreading of mobile uranium species. This research is a lab-scale evaluation of the effectiveness of an in-situ remediation method which consists of a subsurface $\mathrm{pH}$ manipulation by injecting ammonia gas $\left(\mathrm{NH}_{3}\right)$ in order to sequester uranium as insoluble precipitate. 


\section{BACKGROUND AND THEORY}

Hanford Site is a nuclear testing facility located near the Columbia River in the state of Washington, USA. It was built in 1943 as part of the Manhattan Project for the production of the first atomic weapons. The 200 Area is located at the Central Plateau and has the highest elevation. The 200 Area has several large processing facilities called "canyons", burial grounds or "tank farms", hundreds of sites where some of the most hazardous waste was stored, an Environmental Restoration Disposal Facility, a Waste Treatment Plant, office buildings and other operational or abandoned facilities related to the infrastructure of the site. (US Department of Energy., 2016)

The main function of the facilities in the 200 Area was to remove plutonium from the uranium fuel rods after they had been subjected to the nuclear chain reaction in the 100 Area reactors. The technology used at that time generated large amounts of radioactive waste containing uranium and other constituents. Different techniques were used to reduce this waste and to "safely" store it. One method involved storage of some of the most hazardous chemical and nuclear wastes in 177 underground storage tanks spread out among eighteen tank farms, ranging in capacity from 50,000 gallons to more than $1,000,000$ gallons (US Department of Energy., 2016).

As early as 1956, waste leakage from the tanks and underground pipes was suspected, which was confirmed in 1961. The radioactive leaks, consisting of aqueous solutions [acidic and basic with organic complexes (citrate and ethylenediaminetetraacetic acid) and inorganic ligands $\left.\left(\mathrm{CO}_{3}, \mathrm{PO}_{4}\right)\right]$, have been detected in 67 of the 149 single shell tanks. This is not surprising since these tanks have exceeded their design lifetime by more than 30 years. The liquid waste leakages, including about 200,000 kg of uranium (Simpson et al. 
2006), have soaked into the ground at the site and have created multiple plumes of contamination, which are being monitored and treated to remove contaminants. Currently at Hanford, some 53,000,000 gallons of chemical and nuclear waste remain stored in these tanks. Beginning in the 1990s, the site's main activities have revolved around restoring the site to comply with state and federally regulated contaminant levels.

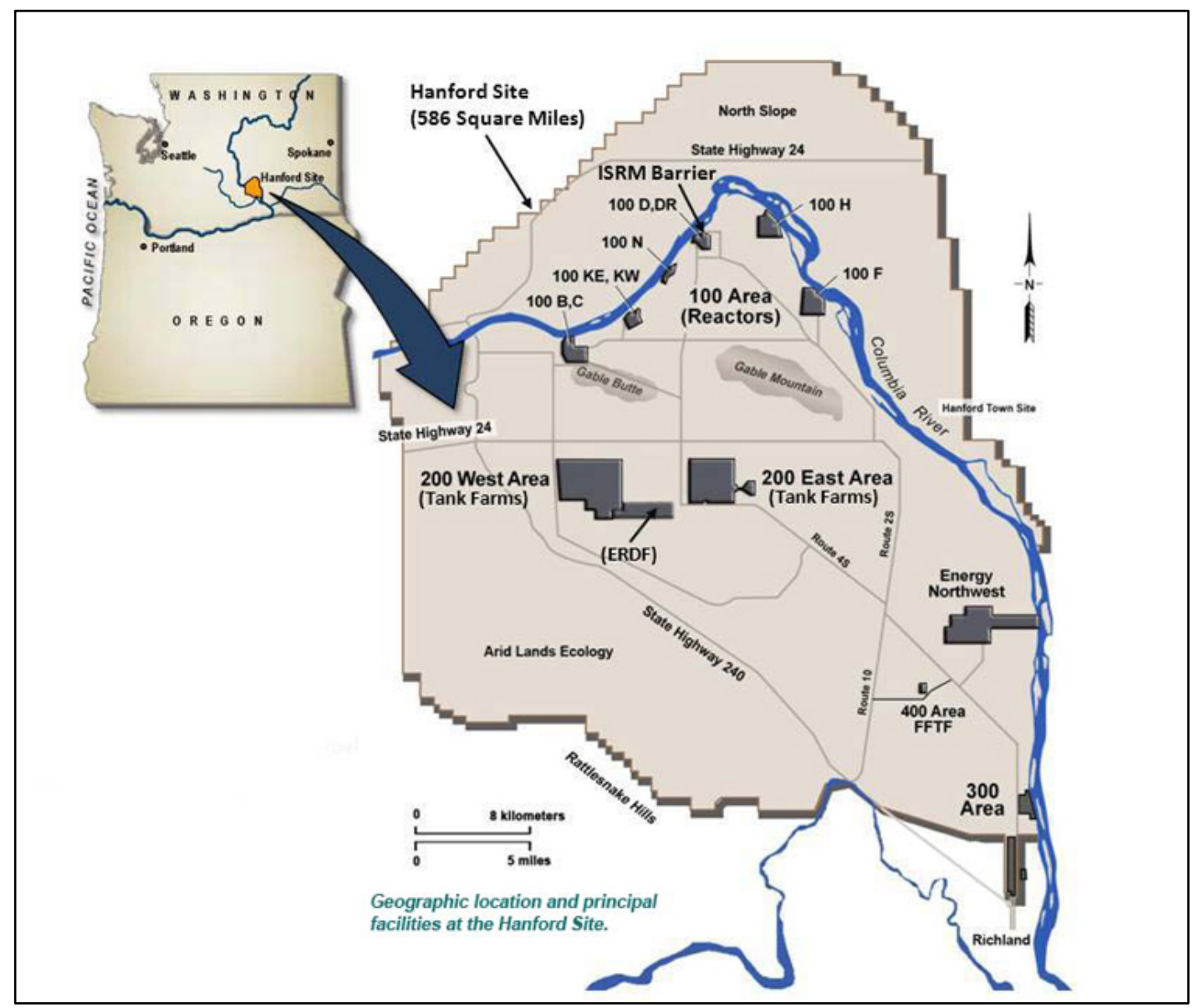

Figure 1: Hanford Site Area. (http://www.hanford.gov/page.cfm/ProjectsFacilities\#HM) 


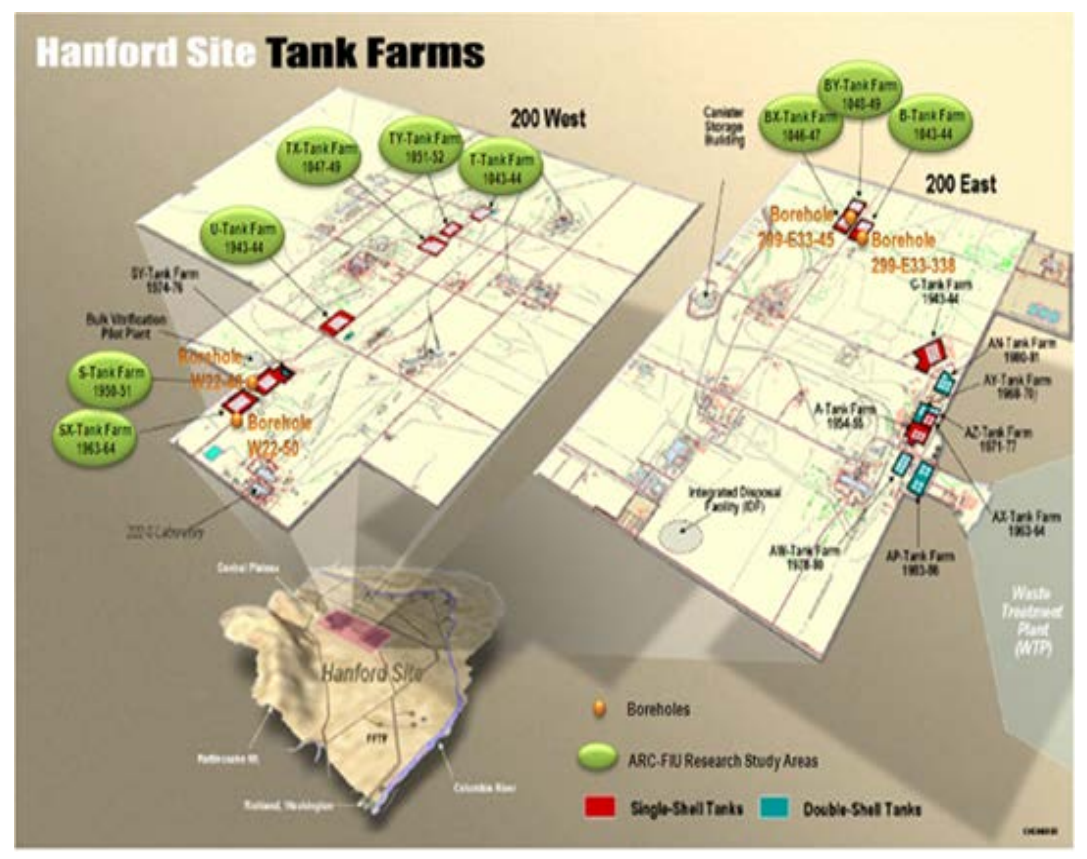

Figure 2: Hanford Site tank farms highlighting ARC-FIU research study areas.

\section{Hanford Site Climatic Conditions}

Due to its location within the semiarid shrub-steppe Pasco Basin of the Columbia Plateau in South Central Washington State, the region's climate is greatly influenced by the Pacific Ocean, the Cascade Mountain Range to the west, and other mountain ranges located to the north and east. The Pacific Ocean moderates temperatures throughout the Pacific Northwest, and the Cascade Range generates a rain shadow that limits rain and snowfall in the eastern half of Washington State. The Cascade Range also serves as a source of cold air drainage, which has a considerable effect on the wind regime at the Hanford Site. Mountains ranges to the north and east of the region shield the area from the severe winter storms and frigid air masses that move southward across Canada. 
The Hanford Site area presents unique climatic characteristics with precipitation from November to March ranging from less than 2.4 in. to more than 8 in. Annual precipitation is $6.8 \mathrm{in}$. Snowfall accounts for about $38 \%$ of all precipitation from December through February. Ranges of daily maximum temperatures vary from $36^{\circ} \mathrm{F}$ in early January to $95^{\circ} \mathrm{F}$ in late July. Finally, occasional high winds of up to 129 kilometers (80 miles) per hour occur throughout the year. (Bunn et al. 2002). Table 1 summarizes the climate average conditions at the Hanford Site.

Table 1. Climate Average Conditions at the Hanford Site

\begin{tabular}{|c|c|c|c|}
\hline Condition & Maximum & Minimum & $\begin{array}{c}\text { Annual } \\
\text { Average }\end{array}$ \\
\hline Temperature $\left({ }^{\circ} \mathrm{F}\right)$ & $\begin{array}{c}93.98 \\
\text { (July) }\end{array}$ & $\begin{array}{c}22.10 \\
\text { (January) }\end{array}$ & 53.3 \\
\hline Precipitation (in) & $\begin{array}{c}1.05 \\
\text { (November) }\end{array}$ & $\begin{array}{c}0.1 \\
\text { (July) }\end{array}$ & 6.8 \\
\hline
\end{tabular}




\section{Stratigraphy}

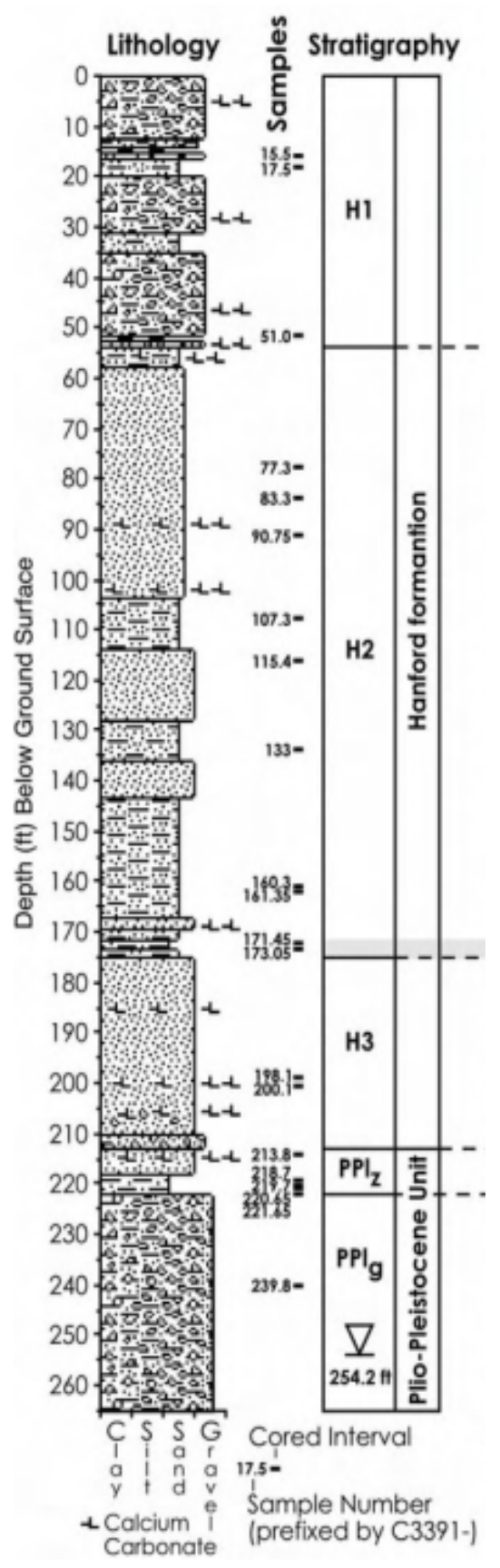

Figure 3: Borehole 299- E33-338 Stratigraphy in 200 East Area (Serne et al., 2002).
The Hanford formation is the uppermost stratigraphic unit and makes up most of the 200 Area vadose zone. It is composed of sediments deposited during several episodes of cataclysmic flooding and consists of poorly sorted sandcontaining lithic fragments from pebble to boulder size, fine-to-coarse-grained sand, and silt (DOE 1988, 2002). The Hanford formation is subdivided into three subunits: $\mathrm{H} 1, \mathrm{H} 2$, and H3, based on composition (Figure 3). The Cold Creek Unit (CCU) follows beneath the Hanford formation and is present only in the 200 West Area (Figure 4) The CCU represents deposits that accumulated within the central Pasco Basin about 2 to 3 million years ago, which brackets two significant geologic events. The older event is a regional base-level drop and subsequent incision of the Ringold Formation (DOE 1988). The younger event is the initiation of Ice Age cataclysmic flooding, which began at the beginning of the Pleistocene, about 1.5 to 2.5 million years ago (Bjornstad et al. 2001). The older event makes up the lower subunit of the CCU and represents a calcium carbonate cemented layer (caliche-rich zone). The

newer event makes up the upper 
subunit and is a well sorted and relatively un-weathered, brown-colored silt-rich deposit. The upper and lower portions of the Cold Creek unit strongly impede the vertical movement of pore fluids in the vadose zone. Beneath the CCU lies the Ringgold formation. The Ringold Formation Unit E is fluvial-deposited pebble-to-cobble gravel with a sandy matrix.

It is characterized by complex interstratified beds and lenses of sand and gravel with low to moderate degrees of cementation (Last et al. 2006)

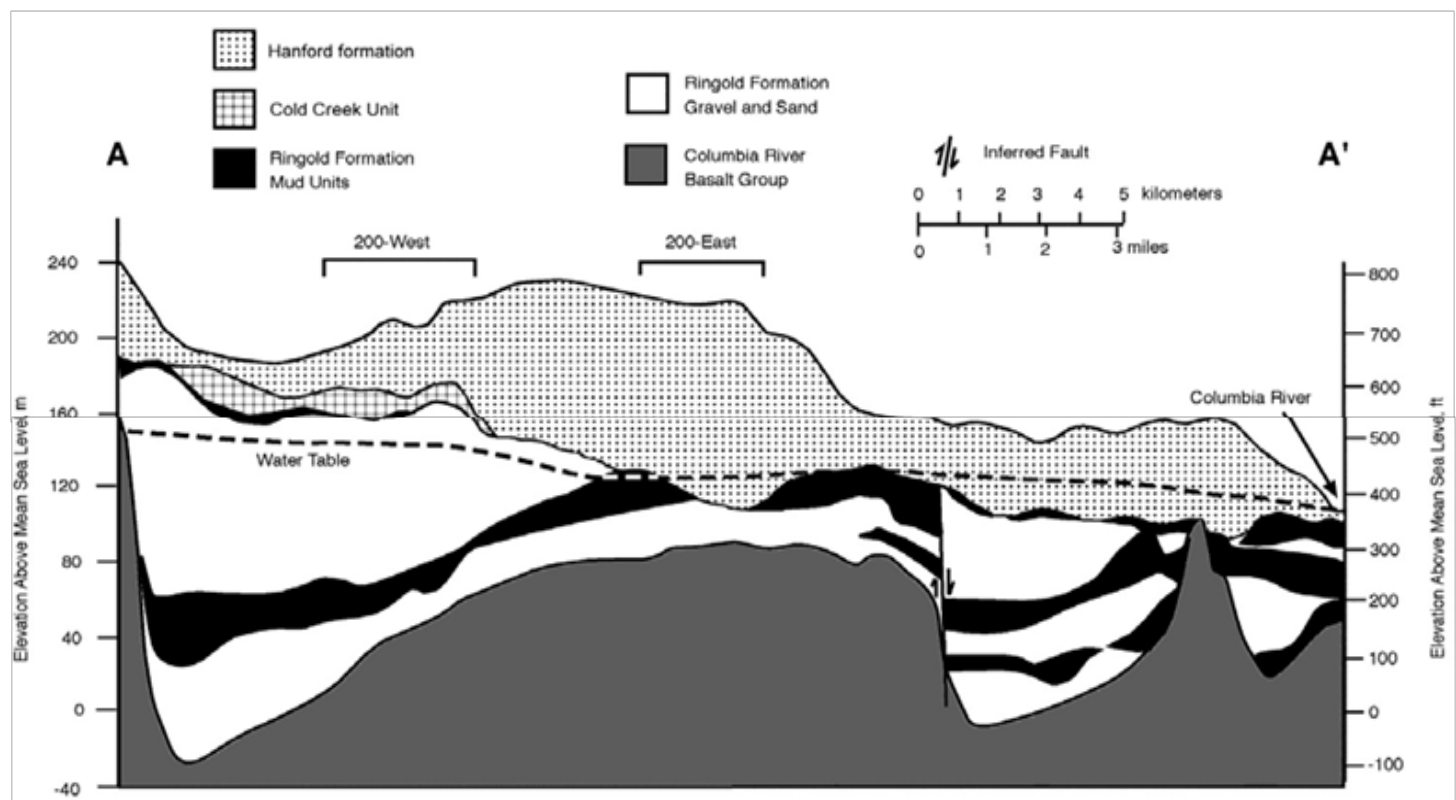

Figure 4: Generalized West-to-East Geologic Cross Section through the Hanford Site (Last et al. 2006)

\section{Hanford Formation Mineralogy}

The 200 East and 200 West areas have similar mineralogy as measured by electron microprobes (Xie et al. 2003). In general, data collected shows dominance by quartz $\left(\mathrm{SiO}_{2}\right)$ ( $45 \%$ to $95 \%$ ), plagioclase feldspar ( $10 \%$ to $20 \%$ ), and alkali feldspar ( $20 \%$ to $40 \%$ ) 
(Serne, 2008) followed by minor amounts of mica, chlorite, and amphibole (Xie, et al. 2003).

The mineralogy of the Hanford formation sediment in the 200 Area is highly variable. Gravel-dominated sediment tends to have a high abundance of lithic fragments (mostly basaltic, with some plutonic, metamorphic, and detrital caliche fragments) (30\% to $50 \%$ of the total) (DOE, 2002), approximately equal amounts of quartz and plagioclase feldspar (15\% to $30 \%)$, and then biotite (2\% to $6 \%)$ and pyroxene ( $0.5 \%$ to $2.5 \%)$ (Bjornstad, 1990$)$. Finer grained facies have proportionally less lithic fragments and more quartz, feldspar, and mica grains. Microprobe analysis of this fraction indicates dominance by quartz (18 to $67.1 \%$ by weight), plagioclase feldspar (5.1 to $41.5 \%$ ) and microcline (1.8 to $30.1 \%$ ) with minor amounts of potassium feldspar $(<10 \%)$ (Tallman, et al. 1979) (Xie, et al. 2003). Overall, approximately $45 \%$ of the clay fraction consists of silicon, followed by lesser amounts of aluminum ( 15\%) and iron ( 12\%) (Serne, 2008).

Hanford formation sediment is typified as having low organic carbon content, generally $<0.1 \%$ by weight, and low-to-moderate cation exchange capacity (2.6 to 7.8 miliequivalents per $100 \mathrm{~g}$ ). Small amounts of detrital calcium carbonate (less than $\sim 3.25$ wt. \%) are common and can act as a weak buffer. The sediment has a slightly basic $\mathrm{pH}$ when wet, ranging from 7.6 to 8.1 (Serne et al. 2008). 


\section{Bulk Chemical Composition}

At Hanford site, silicate content is much higher than the other chemicals in the 200 Area, followed closely by aluminate. In the 200 Area, this is due to the high amount of quartz and feldspars forming rocks in the vadose zone. Other chemicals found with high abundance are calcium and iron, two elements present in the minerals plagioclase and pyroxene composing the basalt in Hanford formation. Bulk sediment samples were characterized for major and trace elements. Overall, results showed very little difference in the primary elemental oxide concentrations for any of the sediment samples as a function of depth or lithology. The primary elemental oxides in decreasing concentration include: $\mathrm{SiO}_{2}\left(58.77\right.$ to 70.33 wt $\%$ ), $\mathrm{Al}_{2} \mathrm{O}_{3}$ (12.7 to 15.73 wt $\%$ ), $\mathrm{Fe}_{2} \mathrm{O}_{3}$ (3.74 to 7.92 wt $\%$ ), $\mathrm{CaO}$ (3.02 to $4.80 \mathrm{wt} \%$ ), $\mathrm{Na}_{2} \mathrm{O}$ (2.05 to $3.23 \mathrm{wt} \%$ ), $\mathrm{K}_{2} \mathrm{O}$ (1.70 to $2.65 \mathrm{wt} \%$ ), $\mathrm{MgO}$ (1.64 to 2.73 wt $\%), \mathrm{TiO}_{2}(0.51$ to $1.39 \mathrm{wt} \%), \mathrm{P}_{2} \mathrm{O}_{5}(0.13$ to $0.30 \mathrm{wt} \%)$, and $\mathrm{MnO}(0.07$ to $0.12 \mathrm{wt} \%)$ (Lindenmeier 2003).

Calcium carbonate is also found abundantly. Content ranges between 1 and $5 \mathrm{wt} \%$ for the Hanford formation (Last et al. 1989) and is as high as $40 \mathrm{wt} \%$ in the Cold Creek unit due to pedogenic alteration and secondary cementation with calcium carbonate (caliche). Content has similar values to the Hanford formation in the Ringold formation (Serne 2008). 


\section{Moisture Content}

Data collected from the three formations from the 200 Area indicates that moisture content in the 200 Area is similar to the overall Hanford site moisture (2.5 to $26 \mathrm{wt} \%$ ) (Serne et al., 2008). Data has also shown that areas where contamination has been identified contain the highest moisture content. For instance, the uncontaminated soils in the 200 West Area near 241-S tank farm and beneath the 241-U Single-Shell Tank Farm generally average less than $10 \mathrm{wt} \%$ and $1 \mathrm{wt} \%$, respectively, while two contaminated soils in the 200 West Area, one near the 241-S tank farm and the other near the tank SX-115, had moisture contents between approximately 2 and $25 \mathrm{wt} \%$ (Serne 2008) and between 2 to $23 \mathrm{wt} \%$, respectively (Lindenmeier et al. 2003).

\section{Pore Water Characterization}

Table 2, adapted from Serne et al (2002), summarizes the average cation content of pore water collected from Borehole 299-E33-338 vadose zone sediment located in the northeast of Hanford Site's 200 Area. 
Table 2: Average Calculated Cation Pore Water Content for Borehole 299-E33-338

\begin{tabular}{|c|c|c|c|}
\hline \multirow{2}{*}{$\begin{array}{c}\text { Average } \\
\text { concentrations, } \\
\text { (mg/L ) }\end{array}$} & $\mathbf{1 6 - 1 0 7 . 8}$ & $\mathbf{1 1 5 . 9 - 1 9 8 . 6}$ & $\mathbf{2 0 0 . 6 - 2 4 0 . 3}$ \\
\cline { 2 - 4 } & $1.38 \pm 1.2$ & $2.07 \pm 1.7$ & $0.52 \pm 0.8$ \\
\hline Aluminum & $0.63 \pm 0.3$ & $0.78 \pm 0.4$ & $0.49 \pm 0.4$ \\
\hline Barium & $157.44 \pm 60.2$ & $162.18 \pm 57.4$ & $111.75 \pm 62.3$ \\
\hline Calcium & $0.63 \pm 0.4$ & $2.39 \pm 2.1$ & $0.64 \pm 1.2$ \\
\hline Iron & $55.61 \pm 13$ & $84.6 \pm 34.9$ & $41.5 \pm 1.2$ \\
\hline Potassium & $35.98 \pm 18.3$ & $41.93 \pm 14.5$ & $24.93 \pm 18.7$ \\
\hline Magnesium & $215.35 \pm 171.6$ & $210.07 \pm 93.5$ & $149.91 \pm 106.7$ \\
\hline Sodium & $139.09 \pm 32.9$ & $199.08 \pm 79.5$ & $118.17 \pm 112.9$ \\
\hline Silicon & $0.73 \pm 0.3$ & $0.91 \pm 0.3$ & $0.610 \pm 0.4$ \\
\hline Strontium & & & \\
\hline
\end{tabular}

Using information from Table 2, it can be concluded that the highest average concentrations of aluminum $(2.07 \mathrm{mg} / \mathrm{L})$, as well as other analyzed elements such as barium, calcium, iron, potassium, magnesium, silicon and strontium, are found at depths between 115.9 to $198.6 \mathrm{ft}$.. However, the highest average concentration of sodium $(215.35$ $\mathrm{mg} / \mathrm{L}$ ) was found at a shallower depth between 16 and $107.8 \mathrm{ft}$.

Pore water collected from the 200 Area was also analyzed for the presence of nitrate and bicarbonate. The characterization of shallow sediments taken from Borehole 299-E33-45 showed the presence of nitrate contamination starting at the contact between the Hanford $\mathrm{H} 1$ and $\mathrm{H} 2$ units at $34 \mathrm{ft}$. bgs., and extending down into the sediment of the fine-grained Plio-Pleistocene Silty Unit, all the way to the water table at 255 feet bgs.. Bicarbonate is one of the major anions calculated (from sediment-to-water extracts). Its concentration in 
the pore water is also elevated in the $\mathrm{H} 2$ middle sand sequence between 75 and $167 \mathrm{ft}$. bgs.; the pore water bicarbonate concentration varies between 0.1 and $0.21 \mathrm{M}$ between 110 to $130 \mathrm{ft}$. bgs. around the paleosol layer, having a peak concentration of $0.21 \mathrm{M}$ at $120 \mathrm{ft}$. bgs.

The concentration of sulfate in pore water samples appear to be slightly elevated and found in the range of 9.6 to $897 \mathrm{mg} / \mathrm{L}$ (1:1 extracts) over the soil vertical profile. The pore water chloride concentrations appear slightly elevated between 70 and $255 \mathrm{ft}$. bgs. (i.e., the water table) with concentrations between 0.7 to $196 \mathrm{mg} / \mathrm{L}$, compared to an average concentration of $1.7 \mathrm{mg} / \mathrm{L}$. The phosphate pore water distribution in the VZ sediment at Borehole 299E33-45 shows elevated concentrations between $\sim 80$ and $130 \mathrm{ft}$. (24.4 to $39.6 \mathrm{~m}$ bgs.) within the $\mathrm{H} 2$ middle sand sequence, in the paleosol at $120 \mathrm{ft}$. bgs., and just below the paleosol to 130 ft. bgs. (Serne et al. 2002).

\section{Uranium Contamination}

Uranium $(\mathrm{U})$ is considered to be one of the primary risk drivers associated with long-term stewardship of the site (Zachara et al. 2007). The great amount of $U$ discharged to the vadose zone, combined with its mobility under the oxidizing, circumneutral-to-mildlybasic geochemical conditions found at Hanford has led to the creation of three identified groundwater plumes (Hartman et al. 2007). These plumes have a combined area of 1.6 square kilometers with dissolved U concentrations that are above the U.S. Environmental Protection Agency’s established maximum-contaminant level (MCL) of $30 \mathrm{ppb}$.

At the Hanford site subsurface, the mobility of uranium in the oxidizing, carbonate-rich subsurface at $\mathrm{pH} \sim 8.0$ is relatively high, with a low $\mathrm{U}(\mathrm{VI})$ adsorption distribution coefficient $\left(\mathrm{K}_{\mathrm{d}}\right)$ averaging $0.11-4 \mathrm{~L} / \mathrm{kg}$. Uranium is present as aqueous or adsorbed phases, 
with the two primary species at $\mathrm{pH} 8$ as neutral and anionic carbonates $\left[\mathrm{Ca}_{2} \mathrm{UO}_{2}\left(\mathrm{CO}_{3}\right)_{3}\right.$ aq and $\left.\mathrm{CaUO}_{2}\left(\mathrm{CO}_{3}\right)_{3}{ }^{2-}\right]$, whereas under highly alkaline conditions, two anion species dominate $\left[\mathrm{CaUO}_{2}\left(\mathrm{CO}_{3}\right)_{3}{ }^{2-}\right.$ and $\mathrm{UO}_{2}\left(\mathrm{CO}_{3}\right)_{3}{ }^{4-}$ [Liu et al., 2008; Zachara et al., 2007]. The mobility of $\mathrm{U}$ (VI) is explained by the formation of highly soluble and stable uranyl carbonate complexes $\left(\mathrm{UO}_{2} \mathrm{CO}_{3}, \mathrm{UO}_{2}\left(\mathrm{CO}_{3}\right)_{2}{ }^{2-}\right.$ and $\left.\mathrm{UO}_{2}\left(\mathrm{CO}_{3}\right)_{3}{ }^{4-}\right)$ (Langmuir 1997, Guillaumont et al. 2003). Uranium is also present in vadose zone at medium to high concentrations as carbonates (liebigite and rutherfordine), co-precipitated with carbonates, hydrous silicates \{uranophane $\left[\mathrm{Ca}\left(\mathrm{UO}_{2}\right)_{2}\left(\mathrm{SiO}_{3} \mathrm{OH}\right)_{2} \cdot 5 \mathrm{H}_{2} \mathrm{O}\right]$ and Na-boltwoodite $\left.\left[\mathrm{Na}\left(\mathrm{UO}_{2}\right)\left(\mathrm{SiO}_{4}\right) \cdot 1.5 \mathrm{H}_{2} \mathrm{O}\right]\right\} \quad$ (Szecsody et al., 2012); additionally it is present in more mobile aqueous and adsorbed phases which is the focus of research investigation of $U$ behavior in this type of environment. Furthermore, uranyl associated with carbonate or phosphate tends to form the most stable aqueous complexes. Nevertheless, precipitation and co-precipitation reactions involving uranyl species will impact $\mathrm{U}$ mobility in the subsurface environment and extractability from sediment (Smith \& Szecsody, 2011).

Uranium is also a naturally occurring element that is present as a trace constituent in the earth's crust. Table 3 contains the concentration of uranium as measured in uncontaminated or background sediment samples. The data has been gathered either via recent fieldsampling and characterization campaigns or is based on historical analyses of site-wide samples (near-surface soils/sediments/rocks and groundwater) since the early 1990s. 
Table 3: Background Uranium-Sediment Concentrations

\begin{tabular}{|c|c|c|c|}
\hline Location & $\begin{array}{c}\text { Average Uranium } \\
\text { Concentration } \\
\text { (mg/kg) }\end{array}$ & $\begin{array}{c}\text { Standard } \\
\text { Deviation }\end{array}$ & Reference \\
\hline WMA-B/BX/BY & 1.47 & 0.55 & Lindenmeier et al. (2003) \\
\hline WMA-T & 2.59 & 0.95 & Serne et al. (2004b) \\
\hline WMA-TX/TY & 2.31 & 0.57 & Serne et al. (2004a) \\
\hline Hanford Site & 2.27 & 0.64 & DOE/RL-96-12 (1996b) \\
\hline
\end{tabular}

Based on the information contained in Table 3, the range of background uranium concentrations in the 200 Area Hanford sediments is from 1.47 to $2.59 \mathrm{mg} / \mathrm{kg}$.

Three different measurement methods of the total uranium content were compared using Borehole 299-E33-45 sediment samples. Data from this contaminated borehole suggests that the significantly elevated uranium-238 activity first appears at $73.4 \mathrm{ft}$. bgs. in the Hanford $\mathrm{H} 2$ unit sediment just above the first thin lens ( $1 \mathrm{ft}$. thick at $74.5 \mathrm{ft}$. bgs.). From about $90 \mathrm{ft}$. to $\sim 111 \mathrm{ft}$. bgs., there is little indication that significantly elevated concentrations of uranium are present. Between 119 and $120 \mathrm{ft}$. bgs., the maximum uranium content reached about $660 \mathrm{mg} / \mathrm{L}$. Below 120ft. bgs. down to $145 \mathrm{ft}$. bgs., the uranium content in the sediment is quite high (reaching values between 200 and $500 \mathrm{mg} / \mathrm{L}$ ). Between 145 and $167.2 \mathrm{ft}$. bgs., in the lower portion of the $\mathrm{H} 2$ middle sequence, there are elevated uranium concentrations (between 50 and $200 \mathrm{mg} / \mathrm{L}$ ). Within the fine grained lens between 167.2 and $169.8 \mathrm{ft}$. bgs., the uranium concentration increases again to values between 200 and $400 \mathrm{mg} / \mathrm{L}$. Below, in the H3 lower sand sequence and the plio-pleistocene sediments, there is no significant indication of elevated uranium, but small concentrations are still present in the sediments. 


\section{Remediation Strategy}

Due to the environmental conditions in the western area of the U.S where typical arid and semi-arid porewater composition, and oxygenated, high-carbonate alkalinity soils are present, remediation of uranium in the deep unsaturated zone (below $100 \mathrm{ft}$. bgs.) is a challenging task. Remediation techniques for the deep vadose zone contaminated with radionuclides are critical for protection of water resources. Remediation of deep vadose zone contamination of radionuclides can potentially be done in-situ by converting aqueous U-carbonate mobile phases to lower solubility precipitates that are stable in the natural environment. Nevertheless, injection of aqueous solutions in the dry vadose zone may potentially cause downward U(VI) migration to the underlying groundwater aquifer.

It is for that reason that injection of gases such as ammonia $\left(\mathrm{NH}_{3}\right)$ to the vadose zone appears a feasible method to decrease uranium mobility in the contaminated subsurface via $\mathrm{pH}$ manipulation and creation of alkaline conditions without causing undesired U(VI) downward migration (Zhong et al., 2015). It has been demonstrated that $\mathrm{NH}_{3}$ treatment of contaminated sediments acts to decrease the highly mobile aqueous and adsorbed $U$ phases by incorporation into precipitates and appears to decrease mobility of some existing $U$ precipitates (Na-boltwoodite) as a result of mineral coating (Szecsody et al., 2012).

The process of this in-situ remediation technique is explained as follows: once $\mathrm{NH}_{3}$ gas is injected in the vadose zone, unreacted $\mathrm{NH}_{3}$ partitioned to the gas phase would slowly migrate upward due to a lower gas density of $0.77 \mathrm{~kg} / \mathrm{m}^{3}$ compared to air density of 1.29 $\mathrm{kg} / \mathrm{m}^{3}$. Ammonia is a highly soluble gas and its injection in the vadose zone can cause the formation of $\mathrm{NH}_{4}^{+}$(which consumes $\mathrm{H}^{+}$) in pore water followed by a subsequent increase 
in $\mathrm{pH}$ up to 12.5 for $100 \% \mathrm{NH}_{3}\left[15.7 \mathrm{~mol} / \mathrm{L} \mathrm{NH}_{3}(\mathrm{aq})\right], 11.9$ [3.1 mol/L NH $\left.3(\mathrm{aq})\right]$ for $5 \%$ $\mathrm{NH}_{3}$ or $\mathrm{pH} 11$ for $0.1 \% \mathrm{NH}_{3}(0.063 \mathrm{~mol} / \mathrm{L})$ (Katsenovich et al., 2016). This $\mathrm{pH}$ manipulation in the $\mathrm{VZ}$ soils may significantly alter the pore water chemistry due to dissolution of the dominant soil minerals such as feldspar, iron oxides, and quartz present in the VZ soil. These dissolution reactions in alkaline conditions potentially induce the release of cations including $\mathrm{Si}, \mathrm{Al}, \mathrm{Ca}, \mathrm{Mg}, \mathrm{Na}$, and $\mathrm{K}$ from soil minerals to pore water (Zhong et al., 2015). Then, upon the re-establishment of natural $\mathrm{pH}$ conditions, various silica and aluminosilicate solid phases, would precipitate as uranium silicates such as the more stable compound Na-boltwoodite causing the formation of uranium-bearing precipitates in the treated vadose zone soil (Szecsody et al., 2013) or decrease U mobility by a coating of U-bearing phases forming a low solubility, non-U precipitate (Bickmore et al., 2001). These chemical reactions can potentially control the mobility of uranyl cations and limit their downward migration to the underlying groundwater aquifer (Szecsody et al., 2012).

Previous short-term laboratory evaluations show a decrease in U mobility after ammonia gas injection in the low water content sediments (Szecsody et al., 2013). Furthermore, Zhong et al. (2015) also indicated that the mass of $\mathrm{U}$ leaching from $\mathrm{NH}_{3}$-treated $\mathrm{U}$ contaminated sediment was significantly less compared to the mass leached from the untreated sediment. However, there has been limited testing of gas remediation technologies such as the one described above (Zhong et al., 2015). 


\section{STATEMENT OF PURPOSE}

\section{Importance of the Study}

Environmental remediation is of great importance to restore sites that have been heavily contaminated by nuclear waste. Uranium has been found to be one of the major pollutants of the Hanford Site 200 Area and represents a great risk to the water resources that are close to the site. Given its toxicity, long half-life ( $4.5 \times 10^{9}$ years), and high mobility in the subsurface, understanding the mechanisms of uranium migration from the DOE nuclear waste disposal sites has become necessary to prevent further contamination and possible exposure hazard to the population of the Washington State. PH manipulations via ammonia $\left(\mathrm{NH}_{3}\right)$ gas injection into the vadose zone has been shown to allow the transformation of mobile uranium species to lower solubility precipitates that are stable in the natural environment (Szecsody et al., 2012). This type of in-situ remediation that will result in sequestration of $\mathrm{U}$ in the deep vadose zone soil and prevent the radioactive contaminant from spreading to the natural water resources is of paramount significance. The scope of this study is to study the stability of the relatively immobile $U$ contained within the precipitates created in the soil after $\mathrm{NH}_{3}$ gas injections. The results are expected to help evaluate the effectiveness of the remediation method for the replicated environmental conditions. 


\section{Research Objective}

Ammonia $\left(\mathrm{NH}_{3}\right)$ gas injections in the vadose zone has been demonstrated to be a viable insitu remediation method to decrease $\mathrm{U}$ mobility in the contaminated subsurface via $\mathrm{pH}$ manipulation, ultimately converting highly mobile complexes to lower solubility Ubearing precipitates that are stable in the natural environment. The purpose of this investigation is to evaluate the stability of the U-bearing precipitates created in the vadose zone soil as a result of ammonia $\left(\mathrm{NH}_{3}\right)$ gas injections as a remediation technology.

\section{Specific Objective}

(i) Description of the relevant environmental conditions prevailing in Hanford Site.

(ii) Preparation of artificial U-bearing precipitates mimicking those created in the subsurface after ammonia gas injection replicating the subsurface conditions present in Hanford Site 200 Area.

(iii) Evaluation of uranium leaching from U-bearing precipitates via sequential extraction experiments.

(iv) Evaluation of $\mathrm{U}$ precipitation/removal efficiencies from $\mathrm{NH}_{3}$-treated synthetic pore water solutions at low Si concentrations 


\section{PROCEDURES AND METHODS}

\section{Sample Preparation}

In order to prepare U-bearing precipitates mimicking those that will be created after $\mathrm{NH}_{3}$ injection at Hanford Site VZ, it was necessary to first study previous characterization done on the dominant pore water composition in terms of concentrations of major cations, anions and $\mathrm{pH}$ to further identify what major components will constitute the samples (Serne, et al. 2008).

For the scope of this study, the large pore water composition was simplified to have five major components in the sample solutions: uranium $(\mathrm{U})$, bicarbonate $\left(\mathrm{HCO}_{3}\right)$, calcium $\left(\mathrm{Ca}^{2+}\right)$, silica ( $\left.\mathrm{Si}\right)$ and aluminum (Al). A low concentration of $\mathrm{U}(\mathrm{VI}) 2 \mathrm{mg} / \mathrm{L}$ and two different bicarbonate concentrations of $3 \mathrm{mM}$ and $50 \mathrm{mM}$ were tested. Three different calcium concentrations $(0,5$ and $10 \mathrm{mM})$ were selected given past observation of $15 \mathrm{mM}$ in $5 \% \mathrm{NH}_{3}$ treated Hanford sediments (Szecsody et al., 2012) The silica concentration used was $50 \mathrm{mM}$ based on past experiments where concentrations reached up to $100 \mathrm{mM}$ in $10 \%$ $\mathrm{NH}_{3}$ treated sediments (Zhong, Szecsody, Truex, Williams, \& Liu, 2015). Aluminum concentration of $5 \mathrm{mM}$ was tested based also on previous studies, which concluded that the concentration of $\mathrm{Al}$ released by $1 \mathrm{~mol} / \mathrm{L} \mathrm{NaOH}$ is relatively small, resulting in $\sim 5.1 \mathrm{mM}$ of Al in the soil solution (Qafoku et al., 2004). It is important to note that Si and Al concentrations are orders of magnitude greater than $U$ which can lead to the potential $U$ precipitation as U-silicates from the $\mathrm{Si}$ and $\mathrm{Al}$ rich solutions (Katsenovich et al., 2016). The following Table 4 summarizes the simplified pore water composition used to prepare the U-bearing precipitate samples. 
Table 4: Target concentrations in synthetic pore water solutions to create U-bearing precipitate samples

\begin{tabular}{|c|c|c|c|c|c|}
\hline Sample ID & Si (mM) & $\mathbf{A l}(\mathbf{m M})$ & $\mathbf{H C O}_{3}(\mathbf{m M})$ & $\mathbf{C a}(\mathbf{m M})$ & $\mathbf{U}(\mathbf{m g} / \mathbf{L})$ \\
\hline $\mathbf{1}$ & 50 & 5 & 3 & 0 & 2 \\
\hline $\mathbf{2}$ & 50 & 5 & 3 & 10 & 2 \\
\hline $\mathbf{3}$ & 50 & 5 & 3 & 15 & 2 \\
\hline $\mathbf{4}$ & 50 & 5 & 50 & 0 & 2 \\
\hline $\mathbf{5}$ & 50 & 5 & 50 & 10 & 2 \\
\hline $\mathbf{6}$ & 50 & 5 & 50 & 15 & 2 \\
\hline
\end{tabular}

\section{a) Preparation of stock solutions}

Stock Solutions of $\mathrm{HCO}_{3}(400 \mathrm{mM}), \mathrm{Si}(422 \mathrm{mM})$, and $\mathrm{Al}(50 \mathrm{mM})$ were first prepared in deionized water (DIW) from the salts $\mathrm{KHCO}_{3}, \mathrm{Na}_{2} \mathrm{SiO}_{3} \cdot 9 \mathrm{H}_{2} \mathrm{O}$, and $\mathrm{Al}\left(\mathrm{NO}_{3}\right)_{3} \cdot 9 \mathrm{H}_{2} \mathrm{O}$, respectively, reaching the desired concentrations in $50 \mathrm{~mL}$ centrifuge tubes, sodium metasilicate, $\mathrm{Na}_{2} \mathrm{SiO}_{3} \cdot 9 \mathrm{H}_{2} \mathrm{O}$, and potassium bicarbonate, $\mathrm{KHCO}_{3}$, were also served as a source of sodium and potassium in the mixture. The $200 \mu \mathrm{g}$ stock solution of uranyl nitrate dissolved in DIW was prepared fresh from a uranyl nitrate hexahydrate $1000 \mu \mathrm{g}$ standard before use (Fisher Scientific). The subsequent Table 5 shows the type and amount of salts used to prepare the necessary stock solutions in $50 \mathrm{~mL}$ volume.

Table 5: Type and amount of salts used to prepare Stock Solutions

\begin{tabular}{|c|c|c|c|c|}
\hline $\begin{array}{c}\text { Stock } \\
\text { Solution }\end{array}$ & Salt Used & $\begin{array}{c}\text { Molecular } \\
\text { Weight of Salt } \\
\text { (g/mol) }\end{array}$ & $\begin{array}{c}\text { Stock Solution } \\
\text { Concentration } \\
\text { (mM) }\end{array}$ & $\begin{array}{c}\text { Amount to } \\
\text { prepare 50 } \\
\text { mL (g) }\end{array}$ \\
\hline Bicarbonate & $\mathrm{KHCO}_{3}$ & 100.114 & 400 & 2.002 \\
\hline Metasilicate & $\mathrm{Na}_{2} \mathrm{SiO}_{3} \cdot 9 \mathrm{H}_{2} \mathrm{O}$ & 284.196 & 422.24 & 5.998 \\
\hline Aluminum & $\mathrm{Al}_{\left(\mathrm{NO}_{3}\right)_{3} \cdot 9 \mathrm{H}_{2} \mathrm{O}}$ & 375.129 & 50 & 0.938 \\
\hline Calcium & $\mathrm{CaCl}_{2} \cdot \mathrm{H}_{2} \mathrm{O}$ & 219.08 & 500 & 5.447 \\
\hline
\end{tabular}




\section{b) Preparation of samples containing U-bearing precipitates}

The general experiment procedure used to prepare 6 samples containing U-bearing precipitates was as follows: first, using $50 \mathrm{~mL}$ centrifuge tubes, prepared two (2) test solutions mixing measured aqueous volumes of $\mathrm{Si}$ and $\mathrm{Al}$ from the prepared stock solutions given $\mathrm{Si} / \mathrm{Al}$ ratio concentration remain the same for all samples; second, measured volumes of the appropriate bicarbonate stock solution was added to the mixture to achieve the targeted concentration ( 3 or $50 \mathrm{mM}$ ). Deionized Water (DIW) was added to each test solution to reach a final volume of $39 \mathrm{~mL}$, leaving $1 \mathrm{~mL}$ of volume for $\mathrm{pH}$ adjustment. Then, the $\mathrm{pH}$ of the resulting solution was measured and adjusted to approximately 8 by titration with concentrated nitric acid $\left(\mathrm{HNO}_{3}\right)$ and DIW was added to end up with a final volume of $40 \mathrm{~mL}$ in each tube. The $\mathrm{pH}$ value is in line with values previously observed in the Hanford Site 200 Area vadose zone (Serne et al., 2008).

Next, 5\% ammonia gas $\left(\mathrm{NH}_{3}\right)$ was injected into the mixture through a metal gas sparger (Mott Corporation, $20 \mu \mathrm{m}$ pores) until the $\mathrm{pH}$ of the solution reached approximately 11 $[0.063 \mathrm{~mol} / \mathrm{L}(\mathrm{aq})]$. This was followed by distribution of the mixture into six $10 \mathrm{ml}$ centrifuge tubes consistent with the 6 different U-bearing precipitate test samples. Finally, the corresponding amount of $\mathrm{U}$ and $\mathrm{Ca}$ were added to each tube. Control samples were prepared in DIW amended with U(VI) at concentration of $2 \mathrm{mg} / \mathrm{L}$ to test for U(VI) losses from the solutions due to sorption to tube walls and caps.

It is important to note that for confirmation purpose, duplicates were prepared for each test sample. In addition, a second set of six original and duplicates samples were prepared following an additional filtration step that will be explained later; therefore, the 
methodology was repeated four times. Tables 6 and 7 below show amount of stock solution and DIW to prepare two $40 \mathrm{~mL}$ tubes of mix samples, which were subsequently distributed into six tubes of $10 \mathrm{~mL}$ mixed samples amended with various concentrations of calcium solutions. The ammonia gas injections and calcium addition caused precipitate formation in each sample.

Table 6: Amount of Stock Solution and DIW to prepare $40 \mathrm{~mL}$ of mixed sample

\begin{tabular}{|c|c|c|c|c|}
\hline Mixture & $\mathbf{S i}(\boldsymbol{\mu L})$ & $\mathbf{A l}(\boldsymbol{\mu L})$ & $\mathbf{H C O}_{3}(\boldsymbol{\mu L})$ & DIW $(\mathbf{m L})$ \\
\hline $\mathbf{1}$ & 4,737 & 4,000 & 300 & 30.963 \\
\hline $\mathbf{2}$ & 4,737 & 4,000 & 5,000 & 26.263 \\
\hline
\end{tabular}

Table 7: Amount of mixed sample, Ca and $U$ to prepared six $10 \mathrm{~mL}$ volume containing $\mathrm{U}$ bearing precipitate samples

\begin{tabular}{|c|c|c|c|c|c|}
\hline $\begin{array}{c}\text { Sample } \\
\text { ID }\end{array}$ & Sample Content & $\mathbf{C a}(\boldsymbol{\mu L})$ & $\mathbf{U}(\boldsymbol{\mu L})$ & $\begin{array}{c}\text { Mixed Sample } \\
(\boldsymbol{\mu L})\end{array}$ & $\begin{array}{c}\text { Total } \\
\text { Sample V } \\
(\boldsymbol{\mu L})\end{array}$ \\
\hline $\mathbf{1}$ & $3 \mathrm{mM} \mathrm{HCO}_{3}, \mathrm{no} \mathrm{Ca}$ & 0 & 200 & 9,800 & 10,000 \\
\hline $\mathbf{2}$ & $3 \mathrm{mM} \mathrm{HCO}_{3}, 5 \mathrm{mM} \mathrm{Ca}$ & 100 & 200 & 9,700 & 10,000 \\
\hline $\mathbf{3}$ & $3 \mathrm{mM} \mathrm{HCO}_{3}, 10 \mathrm{mM} \mathrm{Ca}$ & 200 & 200 & 9,600 & 10,000 \\
\hline $\mathbf{4}$ & $50 \mathrm{mM} \mathrm{HCO}_{3}, \mathrm{no} \mathrm{Ca}$ & 0 & 200 & 9,800 & 10,000 \\
\hline $\mathbf{5}$ & $50 \mathrm{mM} \mathrm{HCO}_{3}, 5 \mathrm{mM} \mathrm{Ca}$ & 100 & 200 & 9,700 & 10,000 \\
\hline $\mathbf{6}$ & $50 \mathrm{mM} \mathrm{HCO}_{3}, 10 \mathrm{mM} \mathrm{Ca}$ & 200 & 200 & 9,600 & 10,000 \\
\hline Control & $\mathrm{DIW}: 9,800 \mathrm{~mL}$ & 0 & 200 & 0 & 10,000 \\
\hline
\end{tabular}

\section{- Unfiltered Samples}

The first set of twelve samples (six original and six duplicates) was selected to be the set of unfiltered samples. All control and experimental tubes were capped and placed in a shaker at $100 \mathrm{rpm}$ at temperature of $25^{\circ} \mathrm{C}$. After letting solid particles within the solutions to settle for approximately 24 hours, the samples were centrifuged using Thermo Scientific, 
Corvall ST 16R centrifuge for 30 minutes at a speed of 5,000 rpm; following, the supernatant solution from each sample was collected in different tubes for future analysis to be able to determine the concentration of $\mathrm{U}$ left in the precipitates. The wet precipitates were set to dry in the oven at $35^{\circ} \mathrm{C}$ for a period of approximately 2-3 weeks. Weights of precipitates were recorded until they were stable, which meant the solid particles were dried.

\section{- $\quad$ Filtered Samples}

The second set of twelve samples (six original and six duplicated) corresponded to the filtered set. The objective of this additional filtration step was to ensure the pore water accumulated inside precipitates was removed before sample drying. The filtration process consisted of vacuum-filtering all the samples using micro sized pore $0,22 \mu \mathrm{m}$ filters and collecting the supernatant solutions in a similar method as the unfiltered samples.

A total of 24 U-bearing precipitate test samples were prepared following the methodology explained in the previous subsections.

\section{Sequential Extraction Experiment}

Though it is typically reserved for soil samples, sequential liquid extractions were conducted to evaluate $\mathrm{U}$ leaching potential from solid precipitates formed and thus the stability of the U-bearing precipitate test samples created in the previous steps. This process allowed the extractability of $\mathrm{U}(\mathrm{VI})$ associated with the solid particles. The sequential extraction experimental approach involved subjecting the solid particles to serial extraction using increasingly aggressive solutions, each intended to target increasingly more difficult 
to remove uranium phases. Each extraction step utilized solutions and conditions chosen specifically to selectively target uranium associated with various phases within the precipitate sample.

A number of sequential extraction procedures have been reported using a wide variety of conditions. While some differences are simply adjustments to fit the sample composition and analyte being targeted, there are many variations for comparable extractions. As many as six different sequential extraction steps have been used to characterize $\mathrm{U}$ in different mineral phases of natural sediments (Smith \& Szecsody, 2011). For the scope of this study, a couple of weak extractants such as deionized water which would access aqueous total $\mathrm{U}$, and carbonate solution, which would remove adsorbed $U$ species were used. In addition, a series of three sequential liquid extractions of increasing strength were employed to generally characterize $\mathrm{U}$ mobility (i.e. harder to extract phases are less mobile): an acetate solution, an acetic acid solution and finally a very strong extractant such as $8 \mathrm{M} \mathrm{HNO}_{3}$ which would remove hard-to-extract $\mathrm{U}$ from uranium-bearing precipitate samples (Table 8). Furthermore, the purpose of these 5 sequential extractions was to quantify the phases that are potentially able to interact with pore water (i.e., aqueous, adsorbed, associated with carbonates and in hydrous silicates) (Szecsody et al., 2012). Adapted from Szecsody (2015), the sequential extraction method, solutions, time of exposure, and target compounds for the experiment are presented in the following Table 8 . 
Table 8: Sequential Extraction Experiment Steps

\begin{tabular}{|c|c|c|c|}
\hline Step & Solution & $\begin{array}{c}\text { Time } \\
\text { (h) }\end{array}$ & Target Compounds \\
\hline 1 & Deionized Water (DIW) & 1 & Aqueous U phases \\
\hline 2 & $\begin{array}{l}\text { Carbonate solution: } 0.0144 \mathrm{M} \mathrm{NaHCO}_{3}+ \\
0.0028 \mathrm{M} \mathrm{Na}_{2} \mathrm{CO}_{3}\left(\mathrm{pH} 9.3 \text { ); } 2 \text { liters: } 2.42 \mathrm{~g} \mathrm{NaHCO}_{3}\right. \\
+0.592 \mathrm{~g} \mathrm{Na}_{2} \mathrm{CO}_{3}+\text { balance DI } \mathrm{H}_{2} \mathrm{O} \text { to } 2.0 \text { liters }\end{array}$ & 1 & Adsorbed U phases \\
\hline 3 & $\begin{array}{l}\text { Acetate solution: } 2 \text { liters: } 136.1 \mathrm{~g} \text { sodium } \\
\text { acetate } 3 \mathrm{H}_{2} \mathrm{O}+30 \mathrm{~mL} \text { glacial acetic acid }(17.4 \\
\text { mol/L), pH 5.0, balance DI } \mathrm{H}_{2} \mathrm{O} \text { to } 2.0 \text { liters }\end{array}$ & 1 & $\begin{array}{l}\text { Dissolved some U- } \\
\text { Carbonates }\end{array}$ \\
\hline 4 & $\begin{array}{l}\text { Acetic acid solution: concentrated glacial acetic } \\
\text { acid, pH } 2.3 ; 2 \text { liters: } 50.66 \mathrm{~mL} \text { glacial acetic acid } \\
(17.4 \mathrm{~mol} / \mathrm{L})+47.2 \mathrm{~g} \mathrm{Ca}\left(\mathrm{NO}_{3}\right)_{2} * 4 \mathrm{H}_{2} \mathrm{O}, \mathrm{pH} 2.3 \text {, } \\
\text { balance } \mathrm{DI} \mathrm{H}_{2} \mathrm{O} \text { to } 2.0 \text { liters }\end{array}$ & 120 & $\begin{array}{l}\text { Most U-Carbonates and } \\
\text { hydrated boltwoodite } \\
\text { (uranyl silicate minerals) }\end{array}$ \\
\hline 5 & $8 \mathrm{M}$ Nitric Acid $\left(\mathrm{HNO}_{3}\right)$ at $95^{\circ} \mathrm{C}$ & 2 & $\begin{array}{l}\text { Dissolved harder } U \\
\text { phases }\end{array}$ \\
\hline
\end{tabular}

Additionally, after each extraction step, samples were rinsed with $5 \mathrm{~mL}$ of deionized water (DIW) which functioned to help remove any lingering extractant. For analytical purposes, this rinse solution was considered a part of the preceding extraction. For the purpose of this study, the extraction volume was selected using a 40:1 solid (mg) to solution (mL) ratio which was used in a PNNL extraction study on uranium in Hanford sediment (Smith and Szecsody 2011).

The extraction procedure began with the addition of the corresponding volume of extraction solution to the labeled vials containing the solid precipitates previously prepared. The mixture was briefly vortexed before being transferred to an orbital shaker where the vessel was agitated at $150 \mathrm{rpm}$ for the duration of the extraction. After each 
extraction, samples were centrifuged at $5000 \mathrm{rpm}$ for 30 minutes in order to separate the extractant and remaining precipitate. As mentioned before, the extraction was followed by a 10 minute DI water rinse, which was also accompanied with agitation and centrifugation steps. This process of extraction and rinse was repeated for extraction steps I through IV with each of their specified extraction times. The final extraction (Step V), intended to target hard to extract uranium species, differed in that its extraction solution used $8 \mathrm{M}$ nitric acid $\left(\mathrm{HNO}_{3}\right)$ maintained at $95^{\circ} \mathrm{C}$ using a water bath.

Following the extractions protocol, all the collected supernatant from the test samples were collected to further be analyzed for trace U.

\section{Low Si Concentration Experiment}

As a result of increasing soil $\mathrm{pH}$ due to ammonia gas injections, the concentration of $\mathrm{Si}$ in pore water has been observed to vary and be as high as $10 \mathrm{~g} \mathrm{~L}^{-1}$ (Szecsody et al., 2010). Additionally, Katsenovich, et al (2016), conducted a study on the role of Si on U (VI) precipitation/removal from $\mathrm{NH}_{3}$-treated synthetic pore water solutions concluding that the process of $\mathrm{U}(\mathrm{VI})$ removal does not seem to be efficient $(<80 \%)$ when the concentration of $\mathrm{Si}$ is less than $50 \mathrm{mM}$. Based on these findings, the objective of this experiment was to quantify the role of the major pore water constituent $\mathrm{Si}$ at low concentrations on uranium (VI) precipitation/removal from $\mathrm{NH}_{3}$-treated synthetic pore water solutions and to find out what is a minimal silica concentration that could sustain U (VI) removal.

For the scope of this study and similar to the sequential extraction experiment, the large pore water composition was simplified to have the following major components in the sample solutions: silica $(\mathrm{Si})$, aluminum $(\mathrm{Al})$, uranium $(\mathrm{U})$, bicarbonate $\left(\mathrm{HCO}_{3}\right)$, calcium 
$\left(\mathrm{Ca}^{+2}\right)$; in addition, samples containing magnesium $(\mathrm{Mg})$ and iron $(\mathrm{Fe})$ instead of calcium were prepared to account for the effect of different pore water composition on $\mathrm{U}$ removal if any. Low silica concentrations tested were 7.5, 15 and $25 \mathrm{mM}$. In addition, aluminum concentration of $5 \mathrm{mM}$, two different bicarbonate concentrations of $3 \mathrm{mM}$ and $50 \mathrm{mM}$, two different calcium and magnesium concentrations of 5 and $10 \mathrm{mM}$, and finally two iron concentrations of 0.2 and $5 \mathrm{mM}$, based on concentrations observed in sediments from the Hanford Site (Szecsody, et al 2010), were tested in three different sets of samples. The following tables 9 and 10 summarize the simplified pore water composition used to prepare the U-bearing precipitate samples for this experiment.

Table 9: Target concentrations in synthetic pore water solutions to create U-bearing precipitate samples containing $\mathrm{Ca}$

\begin{tabular}{|c|c|c|c|c|c|}
\hline Sample & $\mathbf{S i}(\mathbf{m M})$ & $\mathbf{A l}(\mathbf{m M})$ & $\mathbf{H C O}_{\mathbf{3}}(\mathbf{m M})$ & $\mathbf{C a}(\mathbf{m M})$ & $\mathbf{U}(\mathbf{m g} / \mathbf{L})$ \\
\hline $\mathbf{1}$ & 7.5 & 5 & 3 & 0 & 2 \\
\hline $\mathbf{2}$ & 7.5 & 5 & 3 & 5 & 2 \\
\hline $\mathbf{3}$ & 7.5 & 5 & 3 & 10 & 2 \\
\hline $\mathbf{4}$ & 7.5 & 5 & 50 & 0 & 2 \\
\hline $\mathbf{5}$ & 7.5 & 5 & 50 & 5 & 2 \\
\hline $\mathbf{6}$ & 7.5 & 5 & 50 & 10 & 2 \\
\hline $\mathbf{7}$ & 15 & 5 & 3 & 0 & 2 \\
\hline $\mathbf{8}$ & 15 & 5 & 3 & 5 & 2 \\
\hline $\mathbf{9}$ & 15 & 5 & 3 & 10 & 2 \\
\hline $\mathbf{1 0}$ & 15 & 5 & 50 & 0 & 2 \\
\hline $\mathbf{1 1}$ & 15 & 5 & 50 & 5 & 2 \\
\hline $\mathbf{1 2}$ & 15 & 5 & 50 & 10 & 2 \\
\hline $\mathbf{1 3}$ & 25 & 5 & 3 & 0 & 2 \\
\hline $\mathbf{1 4}$ & 25 & 5 & 3 & 5 & 2 \\
\hline $\mathbf{1 5}$ & 25 & 5 & 3 & 10 & 2 \\
\hline $\mathbf{1 6}$ & 25 & 5 & 50 & 0 & 2 \\
\hline $\mathbf{1 7}$ & 25 & 5 & 50 & 5 & 2 \\
\hline $\mathbf{1 8}$ & 25 & 5 & 50 & 10 & 2 \\
\hline
\end{tabular}


Table 10: Target concentrations in synthetic pore water solutions to create U-bearing precipitate samples containing $\mathrm{Mg}$

\begin{tabular}{|c|c|c|c|c|c|}
\hline Sample & Si (mM) & $\mathbf{A l}(\mathbf{m M})$ & $\mathbf{H C O}_{3}(\mathbf{m M})$ & $\mathbf{M g}(\mathbf{m M})$ & $\mathbf{U}(\mathbf{m g} / \mathbf{L})$ \\
\hline $\mathbf{1}$ & 15 & 5 & 3 & 5 & 2 \\
\hline $\mathbf{2}$ & 15 & 5 & 3 & 10 & 2 \\
\hline $\mathbf{3}$ & 15 & 5 & 50 & 5 & 2 \\
\hline $\mathbf{4}$ & 15 & 5 & 50 & 10 & 2 \\
\hline $\mathbf{5}$ & 25 & 5 & 3 & 5 & 2 \\
\hline $\mathbf{6}$ & 25 & 5 & 3 & 10 & 2 \\
\hline $\mathbf{7}$ & 25 & 5 & 50 & 5 & 2 \\
\hline $\mathbf{8}$ & 25 & 5 & 50 & 10 & 2 \\
\hline
\end{tabular}

Table 11: Target concentrations in synthetic pore water solutions to create U-bearing precipitate samples containing Fe

\begin{tabular}{|c|c|c|c|c|c|}
\hline Sample & $\mathbf{S i}(\mathbf{m M})$ & $\mathbf{A l}(\mathbf{m M})$ & $\mathbf{H C O}_{3}(\mathbf{m M})$ & $\mathbf{F e}(\mathbf{m M})$ & $\mathbf{U}(\mathbf{m g} / \mathbf{L})$ \\
\hline $\mathbf{1}$ & 15 & 5 & 3 & 0.2 & 2 \\
\hline $\mathbf{2}$ & 15 & 5 & 3 & 5 & 2 \\
\hline $\mathbf{3}$ & 15 & 5 & 50 & 0.2 & 2 \\
\hline $\mathbf{4}$ & 15 & 5 & 50 & 5 & 2 \\
\hline $\mathbf{5}$ & 25 & 5 & 3 & 0.2 & 2 \\
\hline $\mathbf{6}$ & 25 & 5 & 3 & 5 & 2 \\
\hline $\mathbf{7}$ & 25 & 5 & 50 & 0.2 & 2 \\
\hline $\mathbf{8}$ & 25 & 5 & 50 & 5 & 2 \\
\hline
\end{tabular}

\section{a) Preparation of stock solutions}

Similarly to the Sequential Extraction experiment, Stock Solutions of $\mathrm{HCO}_{3}(400 \mathrm{mM}), \mathrm{Si}$ (422 $\mathrm{mM}), \mathrm{Al}(50 \mathrm{mM})$ were first prepared in deionized water (DIW) from the salts $\mathrm{KHCO}_{3}, \mathrm{Na}_{2} \mathrm{SiO}_{3} \cdot 9 \mathrm{H}_{2} \mathrm{O}$, and $\mathrm{Al}\left(\mathrm{NO}_{3}\right)_{3} \cdot 9 \mathrm{H}_{2} \mathrm{O}$, respectively, reaching the desired concentrations in $50 \mathrm{~mL}$ volume. Likewise, stock solutions of $\mathrm{Ca}(219.08 \mathrm{mM}), \mathrm{Mg}(1250$ $\mathrm{mM})$ and $\mathrm{Fe}(100 \mathrm{mM})$ were prepared in deionized water (DIW) from the salts $\mathrm{CaCl}_{2} \cdot \mathrm{H}_{2} \mathrm{O}$, $\mathrm{H}_{12} \mathrm{O}_{6} \mathrm{MgCl}_{2}$, and $\mathrm{FeCl}_{3} .6 \mathrm{H}_{2} \mathrm{O}$, respectively. The $200 \mu \mathrm{g}$ stock solution of uranyl nitrate dissolved in DIW was prepared fresh from a uranyl nitrate hexahydrate $1000 \mu \mathrm{g}$ standard 
before use (Fisher Scientific). The subsequent Table 12 shows the type and amount of salts used to prepare the necessary stock solutions in $50 \mathrm{~mL}$ volume.

Table 12: Type and amount of salts used to prepare Stock Solutions for Low Si Concentrations Experiment

\begin{tabular}{|c|c|c|c|c|}
\hline Stock Solution & Salt Used & $\begin{array}{c}\text { MW of Salt } \\
\text { (g/mol) }\end{array}$ & $\begin{array}{c}\text { Stock Solution } \\
\text { Concentration (mM) }\end{array}$ & $\begin{array}{c}\text { Amount to prepare } \\
\mathbf{5 0 ~} \mathbf{~ m L} \text { (g) }\end{array}$ \\
\hline Bicarbonate & $\mathrm{KHCO}_{3}$ & 100.114 & 400 & 2.002 \\
\hline Metasilicate & $\mathrm{Na}_{2} \mathrm{SiO}_{3} \cdot 9 \mathrm{H}_{2} \mathrm{O}$ & 284.196 & 422.24 & 5.998 \\
\hline Aluminum & $\mathrm{Al}_{\left(\mathrm{NO}_{3}\right)_{3} \cdot 9 \mathrm{H}_{2} \mathrm{O}}$ & 375.129 & 50 & 0.938 \\
\hline Calcium & $\mathrm{CaCl}_{2} \cdot \mathrm{H}_{2} \mathrm{O}$ & 219.08 & 500 & 5.447 \\
\hline Magnesium & $\mathrm{H}_{12} \mathrm{O}_{6} \mathrm{MgCl}_{2}$ & 203.3 & 1250 & 12.706 \\
\hline Iron & $\mathrm{FeCl}_{3} \cdot 6 \mathrm{H}_{2} \mathrm{O}$ & 270.32 & 100 & 1.3516 \\
\hline
\end{tabular}

\section{b) Preparation of U-bearing precipitates samples}

Excluding the additional filtration steps, the same procedure as that explained and followed in the sequential extraction experiment was followed. A total of 34 samples and duplicated unfiltered samples were prepared following the protocol.

\section{Analytical Procedure}

Samples of the supernatant from each vial were analyzed using a kinetic phosphorescence analyzer (KPA-11, Chemchek Instrument, Richland, WA) instrument to determine: a) the remaining $\mathrm{U}$ (VI) concentration left in the solution after preparation of U-bearing precipitates in both sequential extraction and low Si concentration experiments, and b) the extracted U (VI) concentration after each sequential extraction and rinsing step. For analysis with the KPA instrument, an aliquot was extracted from the supernatant of each test sample and diluted with $1 \%$ nitric acid between 5 and 100 times. 


\section{RESULTS AND DISCUSSION}

\section{Sequential Extraction on Unfiltered Samples}

The KPA data collected from the analysis was graphed to display the mass of uranium removed with each extraction step based on the determined uranium concentration and the volume that it was extracted into. Figure 5 displays the total mass of uranium removed from the unfiltered test samples precipitates during sequential extraction experiment. These precipitates contained some remaining pore water inside that was dried with the solids.

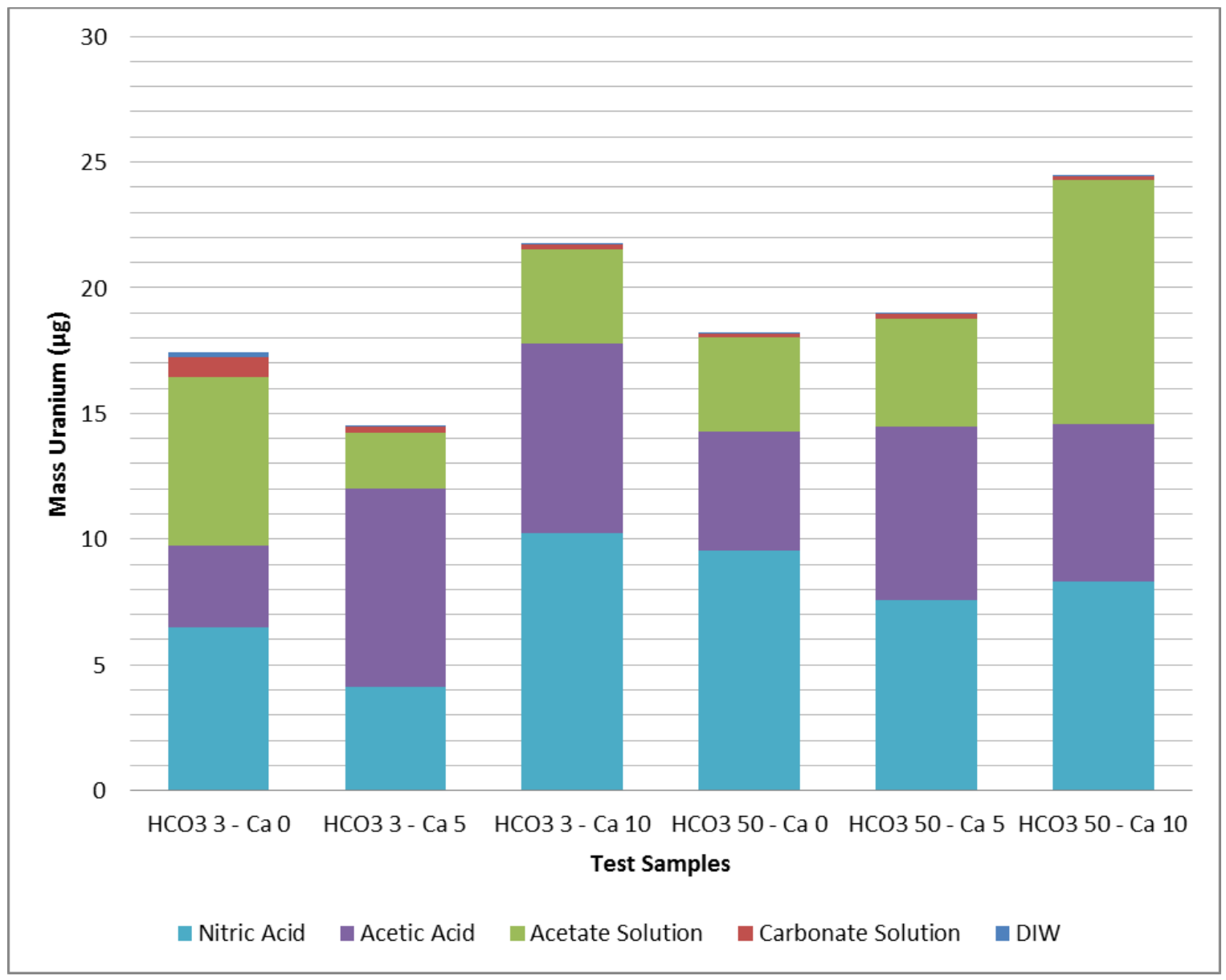

Figure 5: Sequential Uranium Extraction of Unfiltered Sample Precipitates on Mass Basis 
Observing Figure 5, the total mass of uranium extracted shows that each low bicarbonate samples had less uranium removed than their high bicarbonate counterparts. Additionally, the highest calcium containing samples resulted in the greatest uranium removal.

A comparison of the relative removal of uranium between the various extraction steps reveals how each extracting solution was favored in the different samples. This is useful for developing an assumption of the types of uranium phases, which are most prevalent based on the "targeted" extraction phase (Refer to Table 8) and the relative mass of the analyte removed by its corresponding solution. Figures 5 and 6 exhibit the $\mathrm{U}$ extraction distribution on a percent basis for both "low" and "high" $\mathrm{HCO}_{3}$ samples.

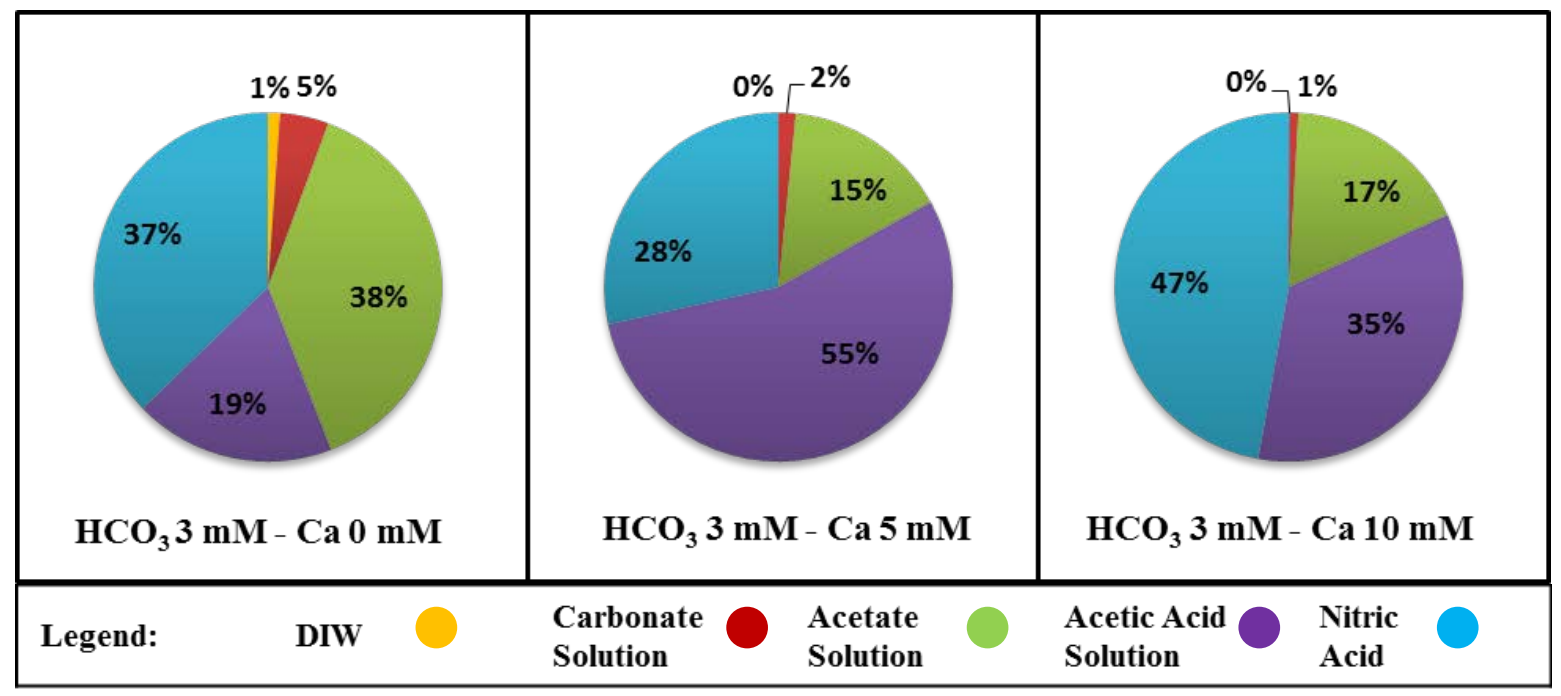

Figure 6: Uranium Extraction Distribution for unfiltered low $\mathrm{HCO}_{3}$ samples 


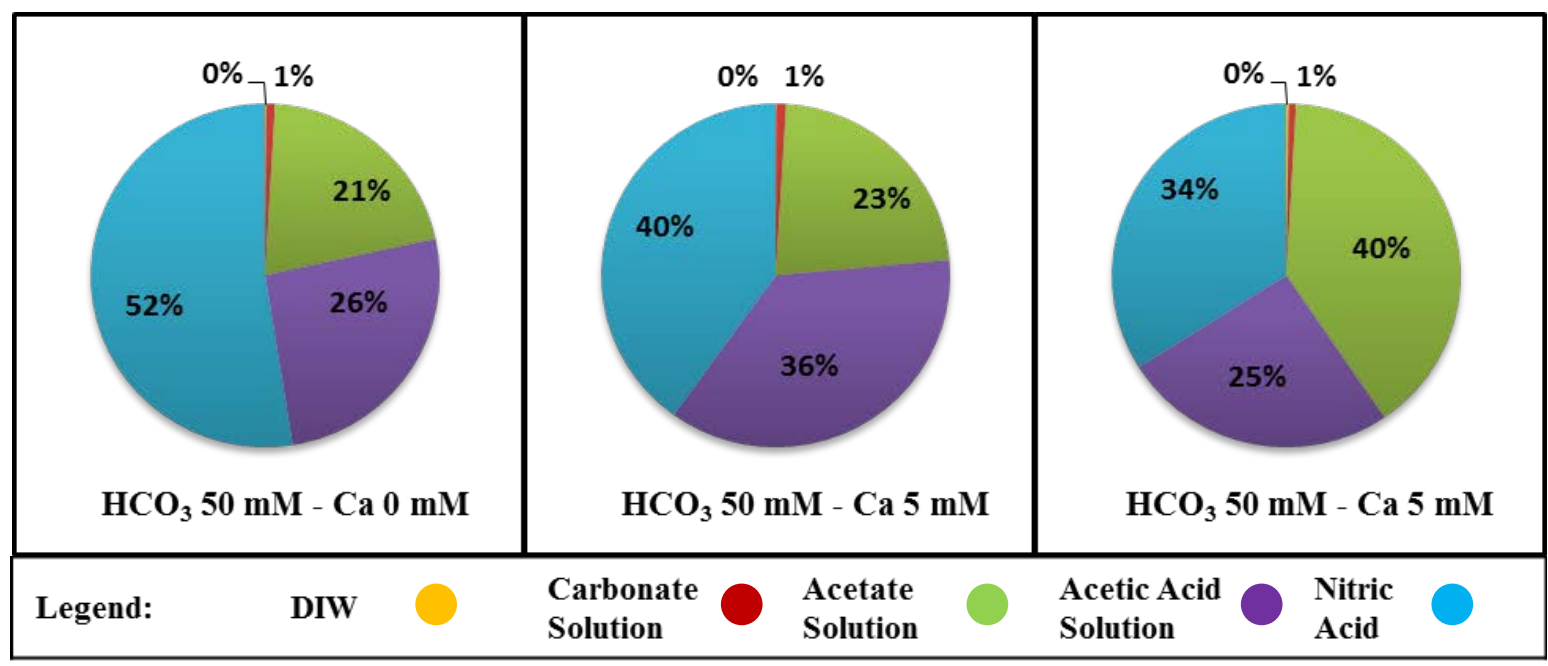

Figure 7: Uranium Extraction Distribution for unfiltered high $\mathrm{HCO}_{3}$ samples

The sequential extraction distribution charts reveal that there is a near insignificant uranium removal in the less aggressive DIW and carbonate solution extractions, suggesting uranium species were not present in the soluble phases. In addition, between equivalent "low" and "high" bicarbonate samples, the carbonate extraction, which targets the adsorbed species, had a decrease. The relative uranium removal decreased from $2-5 \%$ to $1 \%$ indicating less adsorbed U-phases formed at higher $\mathrm{HCO}_{3}$ concentrations. Furthermore, it is clear that most uranium was removed in the acetate solution and nitric acid, step 3 and 4 respectively, suggesting that the uranyl carbonates and silicates make up the bulk of the extracted analyte.

\section{Sequential Extraction on Filtered Samples}

Similarly to the unfiltered set of samples, the KPA data collected from the analysis was graphed to display the mass of uranium removed with each extraction step based on the determined uranium concentration and the volume that it was extracted into. Figure 8 
displays the total mass of uranium removed from the filtered test samples precipitates during sequential extraction experiment.

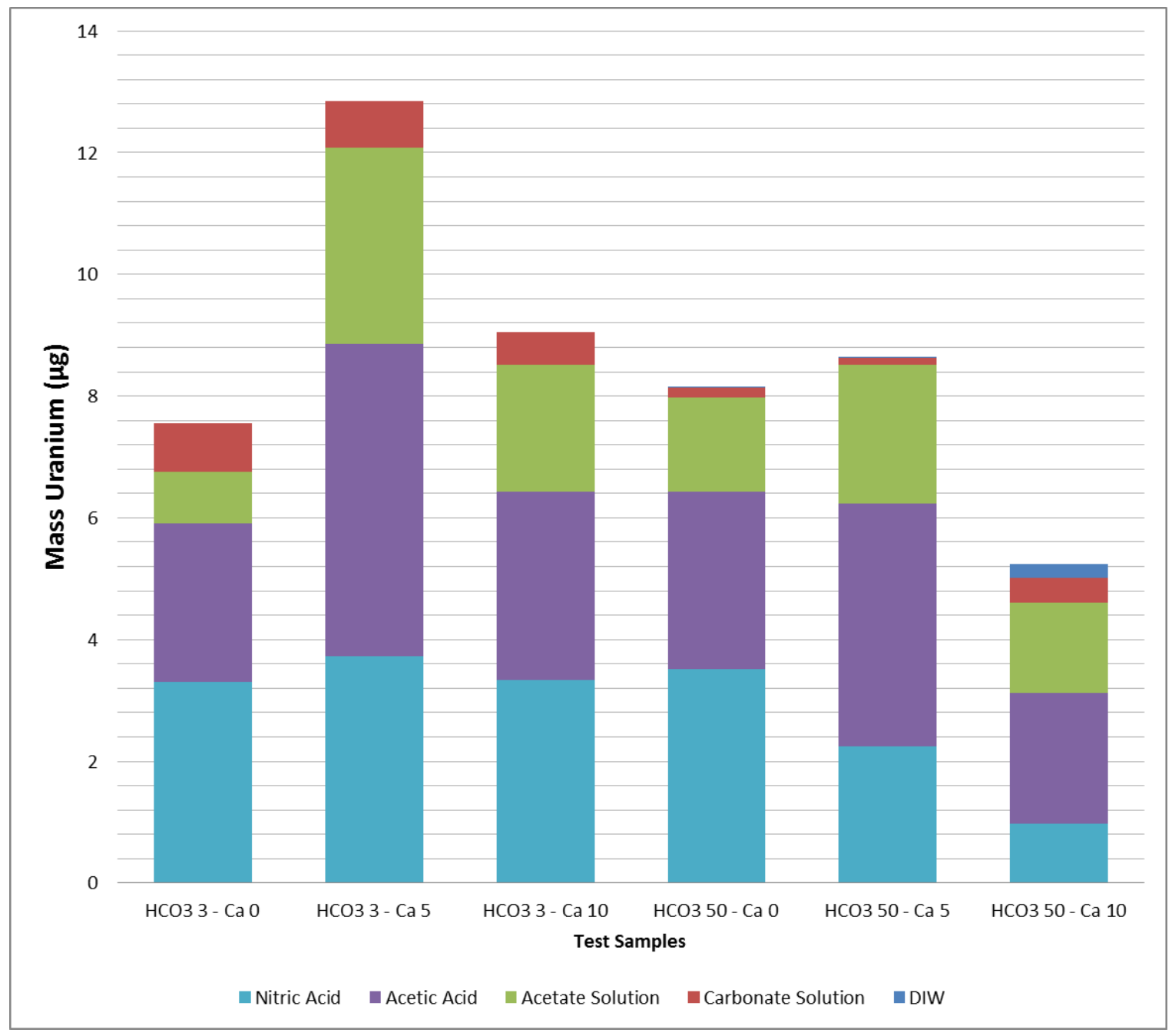

Figure 8: Sequential Uranium Extraction of Filtered Sample Precipitates on Mass Basis

It can be noted that in this case, the total mass of uranium extracted shows that in general, low bicarbonate test samples had greater uranium removal than their high bicarbonate counterparts except for the samples containing $5 \mathrm{mM}$ of calcium. Additionally, the high bicarbonate sample containing $10 \mathrm{mM}$ of calcium resulted in greater uranium removal during the first extraction than all of the samples previously tested. This could be explained 
by the fact that some solid uranium-bearing particles might have been inadvertently collected during KPA analysis, consequently causing an incorrect supernatant uranium concentration result.

Figures 9 and 10 below are presented, likewise the unfiltered samples, with the sole purpose of developing an assumption of the types of uranium phases which are most prevalent based on the "targeted" extraction phase and the relative mass of the analyte removed by its corresponding solution. Figures 9 and 10 show the uranium extraction distributions on a percentage basis for unfiltered low and high $\mathrm{HCO}_{3}$ samples.

Figure 9: Uranium Extraction Distribution for filtered low $\mathrm{HCO}_{3}$ samples

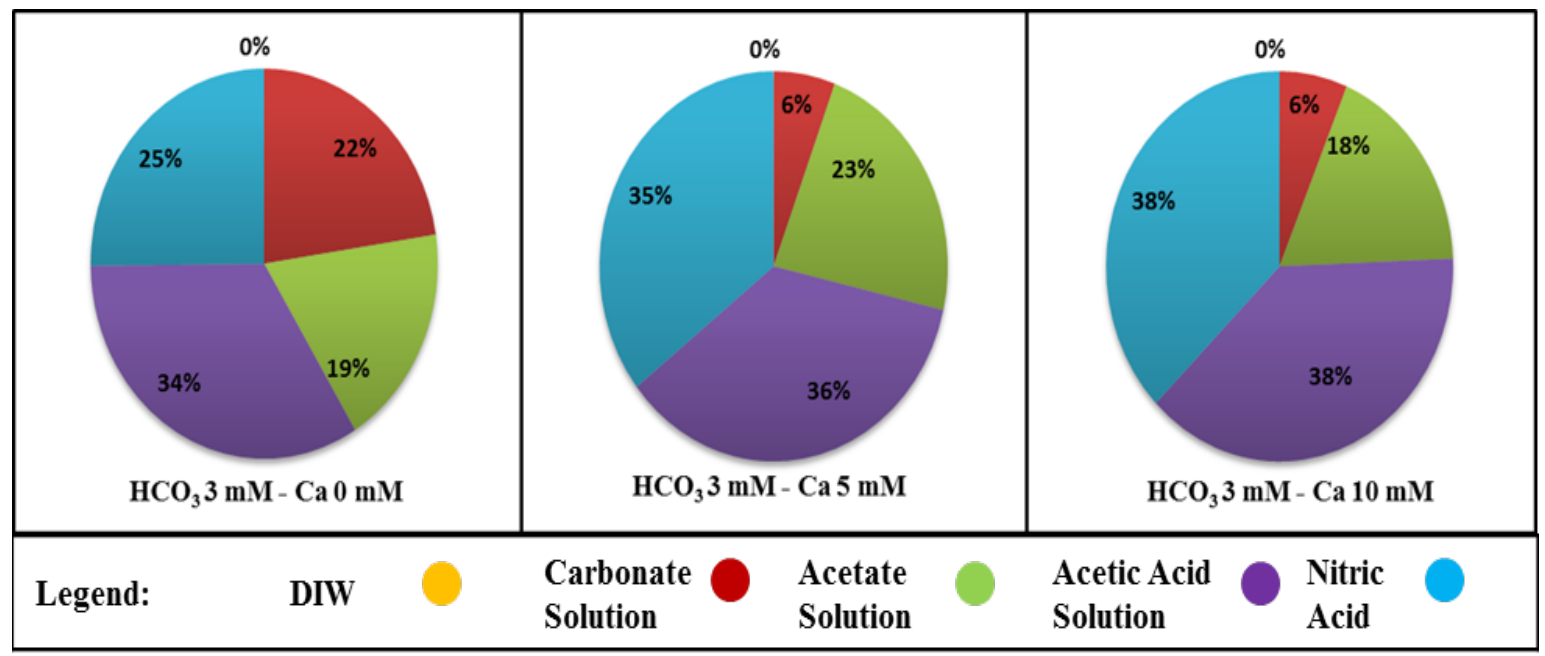




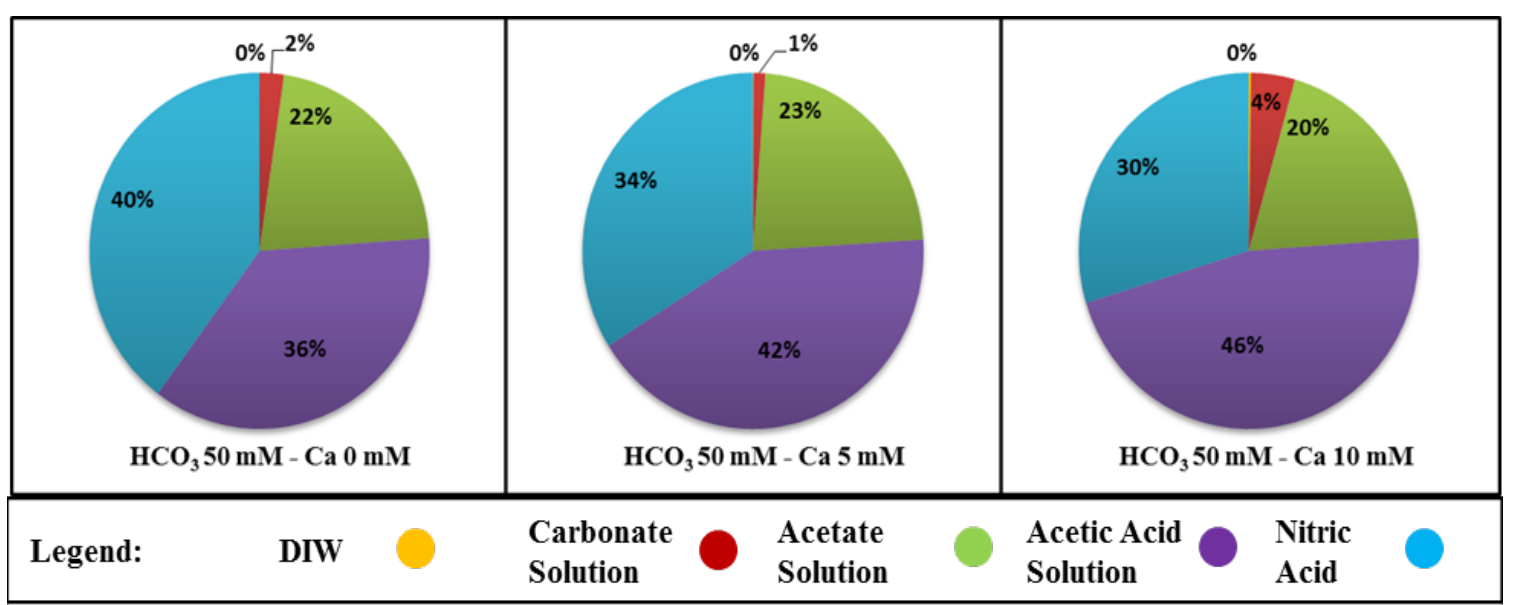

Figure 10: Uranium Extraction Distribution for filtered high $\mathrm{HCO}_{3}$ samples

The results obtained from the filtered test samples analysis represented in the sequential extraction distribution charts also reveal that there is a near insignificant uranium removal in the less aggressive DIW and carbonate solution extractions, suggesting uranium species were not present in the soluble phases. In addition, between equivalent low and high bicarbonate samples, the carbonate extraction, which targets the adsorbed species, had a significant decrease. The relative uranium removal decreased from $6-25 \%$ to $1-4 \%$. Furthermore, it is clear that the majority of uranium was removed in the acetate solution and nitric acid, step 3 and 4 respectively, suggesting that the uranyl carbonates and silicates make up the bulk of the extracted analyte. Also, it should be noted that these filtered samples didn't contain pore water, only uranium that complexed with $\mathrm{Si}$, adsorbed on the Si surface or was incorporated inside the solid phases. 


\section{Synthetic Pore Water Optimization and Mass Balance}

The results of previous attempts to account for total mass of $U$ removed after sequential extractions showed a relatively lower amount of $U$ analyte in the precipitate compared to the amount of $U$ injected. To counter this, the optimization study focused on what component concentrations would maximize the fraction of $U$ in the precipitate phase based on the concentrations of $U$ left in their supernatants, or in other words, the $U$ removal efficiency. This relied on the assumption that all uranium introduced to the sample solutions was either retained in solution or precipitated/adsorbed onto the solid phase.

The optimization experiment was designed such that the results of the KPA analysis of the filtered supernatant solutions could be visualized using response surface diagrams (Figure 11). The full factorial experimental design took into account all test concentrations to display the relationship between the two variable concentrations and the concentration of uranium in the supernatant phase. 


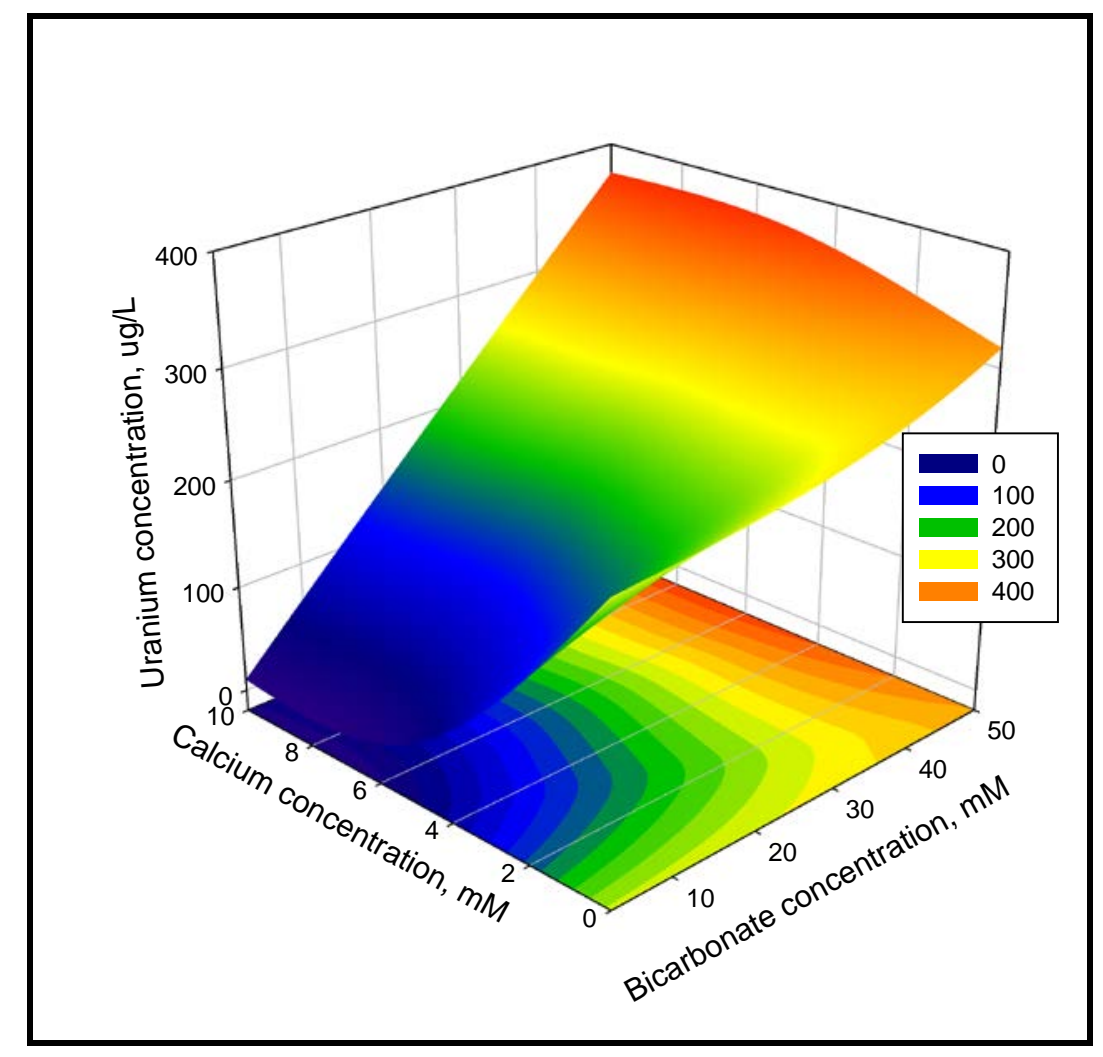

Figure 11: Response surface diagrams displaying filtrate solution uranium retention in samples

The results of the samples set show a clear and demonstrative positive correlation between the increasing concentration of bicarbonate in synthetic pore water solutions and the concentration of uranium in the filtered post-treated supernatant solution. This finding suggests that with increasing sample bicarbonate concentration, the amount of uranium in the precipitate decreases. It is therefore safe to conclude that the high bicarbonate samples would be least likely to precipitate the uranium analyte.

This observed trend of uranium in the supernatant solutions increasing with added bicarbonate is likely indicative of conditions increasingly favoring the formation of uranyl carbonates. These species, which are very stable and highly soluble in aqueous solutions, form charged complexes, which can adsorb to the surface solid minerals under the right 
$\mathrm{pH}$ conditions. On the other hand, the trends in Figure 11 show that low bicarbonate samples have the least uranium remaining in the supernatant solutions and should, therefore, have the most in the precipitate phase. This may be explained by the formation of uranyl silicates which are relatively stables in the solid phases.

Additionally, observing Figure 11, there is correlation between the increasing calcium concentrations in sample solution and the concentration of uranium in the supernatant. Nevertheless, unlike bicarbonate, the increasing calcium is associated with a decrease of uranium concentration in solution and, therefore, an increase in the uranium precipitated. It is theorized that the increase in calcium could favor the removal or uranium and one possible explanation is that the increase in calcium results in the precipitation of less soluble solids, such as calcium carbonates or calcium silicates, which could serve as nucleation sites provoking Si polymerization reactions and precipitation of silica (Iler, 1979). When silica precipitates, this can also lead to co-precipitation of uranium. Finally, it is also important to note that in all cases the technology was effective in removing $\mathrm{U}$ from the synthetic pore water solutions. In fact, considering the concentration of U injected as $2000 \mu \mathrm{g} / \mathrm{L}$, the $\mathrm{U}$ precipitation/removal efficiencies from the aqueous phases ranged between $75-98 \%$. 


\section{Low Si Concentrations Experiment}

Experimental results were calculated as percent removal of U (VI) from the supernatant solutions. The removal values for the contaminant were plotted on the y-axis against the initial concentration of $\mathrm{Si}$ on the X-axis (Figures 12 and 13). These graphs were used to compare results for each data set prepared with different $\mathrm{HCO}_{3}$ concentrations $(3 \mathrm{mM}$ as "low" and $50 \mathrm{mM}$ as "high").

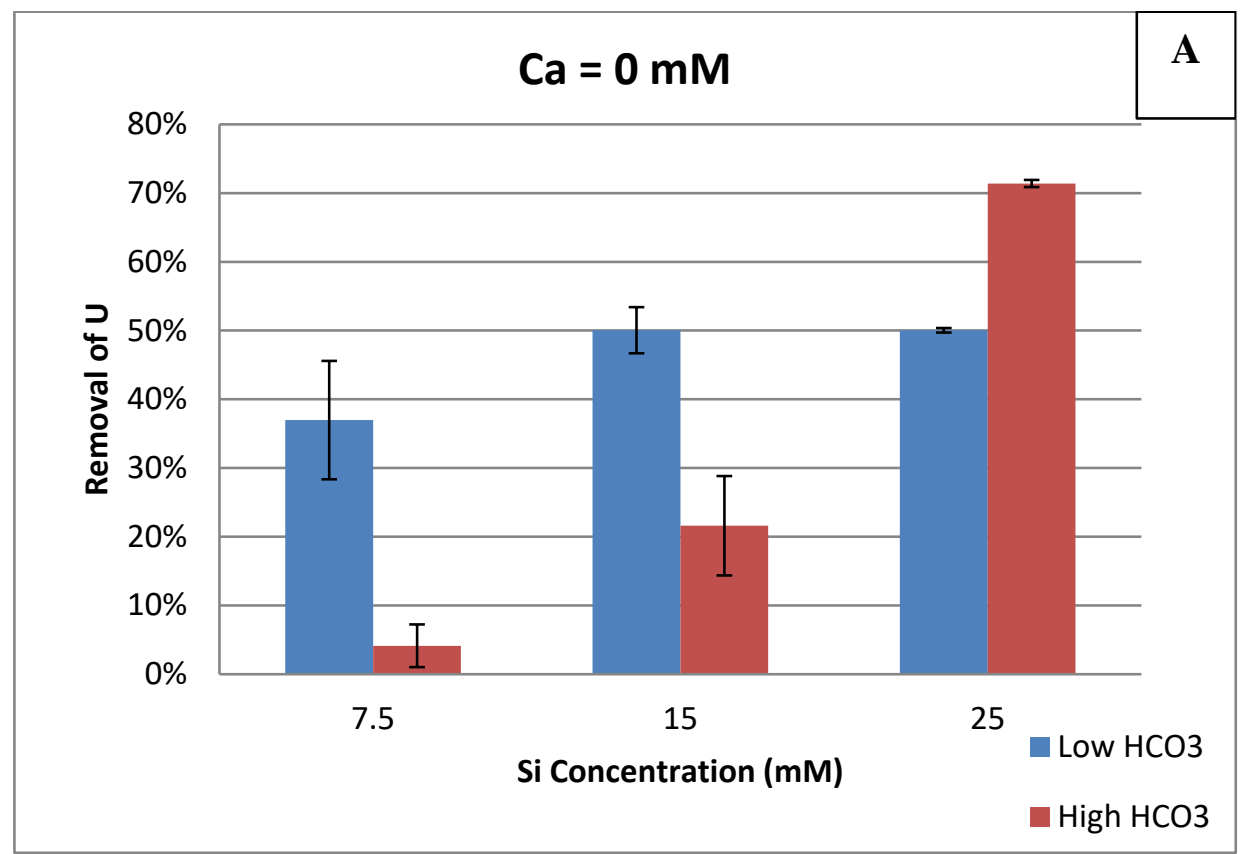



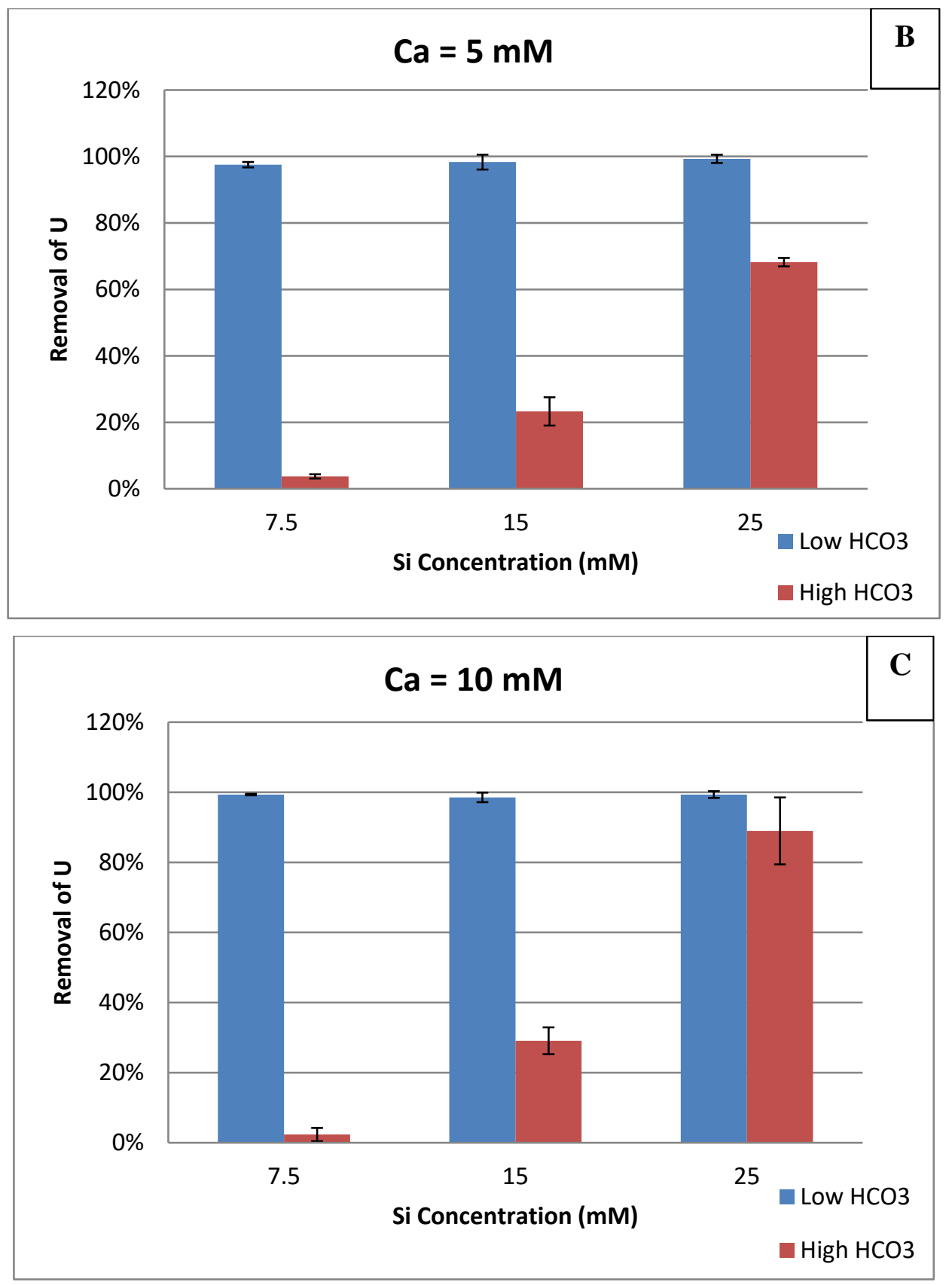

Figure 12: Percent removal of U (VI) tested at variable bicarbonate and silica concentrations in $5 \mathrm{mM}$ Al amended solutions containing $2 \mathrm{mg} / \mathrm{L} \mathrm{U}$ (VI) and (A) $0 \mathrm{mM}$; (B) $5 \mathrm{mM}$; and (C) $10 \mathrm{mM}$ of $\mathrm{Ca}$

Generally, at Ca concentration of $0 \mathrm{mM}$ and $\mathrm{Si}$ concentration of $15 \mathrm{mM}$, the removal efficiency of $U$ resulted in the relatively low values, averaging less than $50 \% \pm 20 \%$ 
including both low and high bicarbonate concentrations (Fig. 12A). Also, the presence in the solution composition of "high" bicarbonate concentration $(50 \mathrm{mM})$ appears to significantly reduce the removal efficiency of $\mathrm{U}$ at $\mathrm{Si}$ concentration of $15 \mathrm{mM}$ as oppose to improving removal efficiency of $\mathrm{U}$ at $\mathrm{Si}$ concentration of $25 \mathrm{mM}(71 \% \pm 2 \%)$. This trend was observed only at $\mathrm{Ca}$ concentration of $0 \mathrm{mM}$ in the solution composition (Fig. 12A). This can be explained by the formation of calcium carbonates or calcium silicates, which could provoke Si coagulation and precipitation reactions leading to co-precipitation of uranium. In the absence of $\mathrm{Ca}$, the co-precipitation of $\mathrm{U}$ can only occur in case of $\mathrm{Si}$ polymerization reactions that require much higher Si content on the level of Si solubility concentrations at alkaline conditions. Furthermore, it is evident that, for all three $\mathrm{Ca}$ concentrations tested, at high bicarbonate concentrations, removal efficiency of $U$ improves as concentration of Si increases (Fig. 12A, 12B and 12C). Moreover, the data collected suggests that at both $\mathrm{Si}$ concentrations of 15 and $25 \mathrm{mM}$, U (VI) removal efficiency reduces as the concentration of bicarbonate is higher; the gap in this reduction is smaller at $\mathrm{Si}$ concentrations of $25 \mathrm{mM}$ (Fig. 12B and 12C). According to Katsenovich, et al (2016), at $\mathrm{HCO}_{3}>25 \mathrm{mM}$ stable soluble uranyl carbonate species such as $\mathrm{UO}_{2}\left(\mathrm{CO}_{3}\right)_{3}^{-}$ ${ }^{4}$ become predominant at alkaline conditions. This might explain the relatively lower removal efficiency of U compared to "low" bicarbonate concentrations where uranium is present in the uranyl hydroxide form. The highest removal efficiency of $U$ up to $99 \%$ was achieved in the compositions containing "low" bicarbonate concentration for all $\mathrm{Ca}$ and $\mathrm{Si}$ concentrations tested. (Fig. 12) 

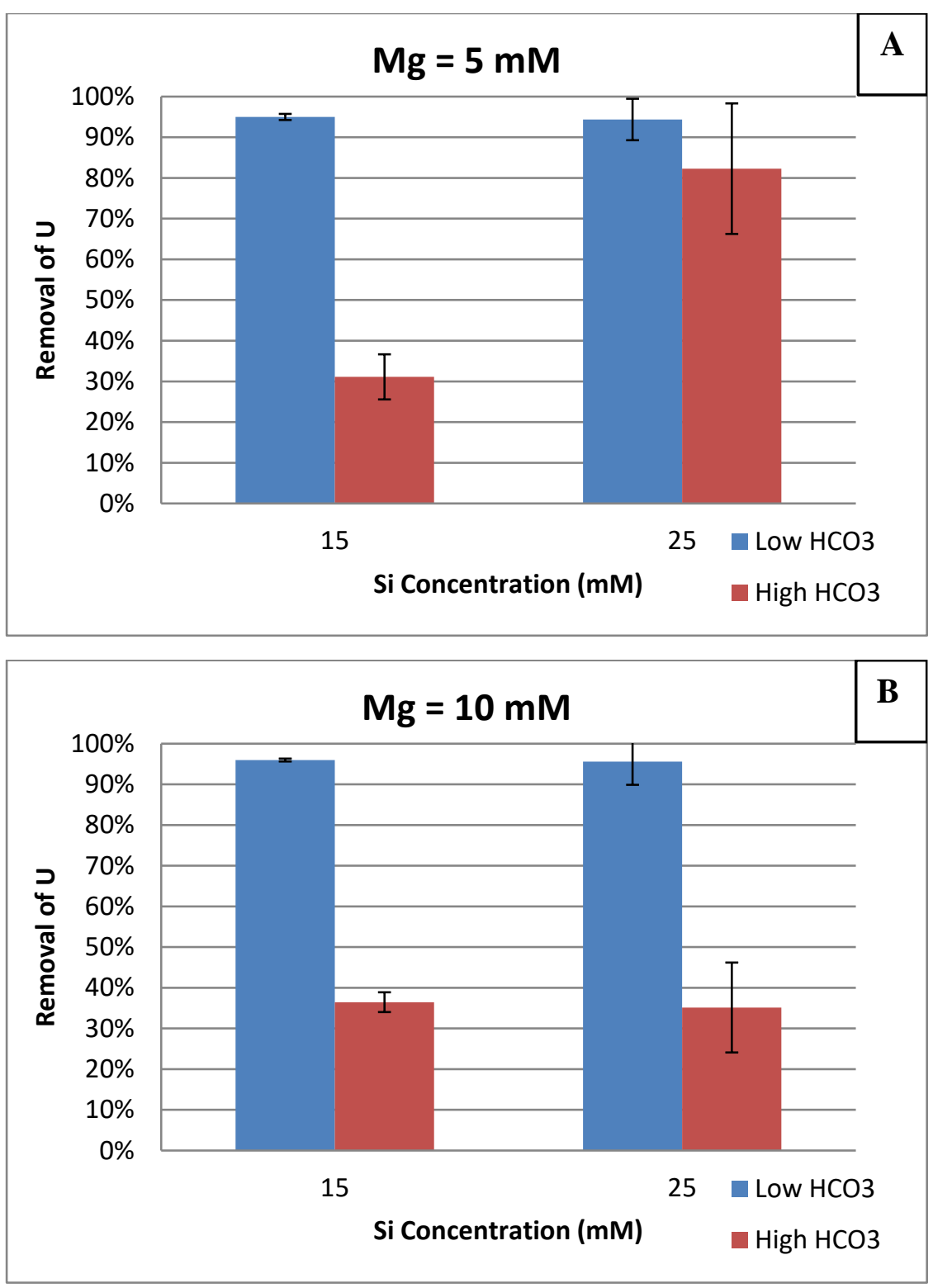

Figure 13: Percent removal of $U$ (VI) tested at variable bicarbonate and silica concentrations in $5 \mathrm{mM}$ Al amended solutions containing $2 \mathrm{mg} / \mathrm{L} \mathrm{U}$ (VI) and (A) $5 \mathrm{mM}$; and (B) $10 \mathrm{mM}$ of $\mathrm{Mg}$

Samples containing $\mathrm{Mg}$ which is one of the major constituent in the pore water composition, showed similar trends in removal efficiency of U (VI) as previously was observed for samples containing Ca. First, at "low" bicarbonate concentrations, Si concentrations of 15 and $25 \mathrm{mM}$ and $\mathrm{Mg}$ concentrations of 5 and $10 \mathrm{mM}$, the removal 
efficiency of $U$ (VI) was greater than $94 \%$. In addition, the data also demonstrated the higher bicarbonate concentration correlates with a significant lower removal efficiency of $\mathrm{U}(\mathrm{VI})$ at Si concentrations of 15 and $25 \mathrm{mM}$ and $\mathrm{Mg}$ concentrations of 5 and $10 \mathrm{mM}$ (Fig. 2A and 2B). Finally, it is visible that higher $\mathrm{Si}$ concentrations improve the general removal efficiency of U (VI) at "low" bicarbonate concentration and $\mathrm{Mg}$ concentrations of $5 \mathrm{mM}$.

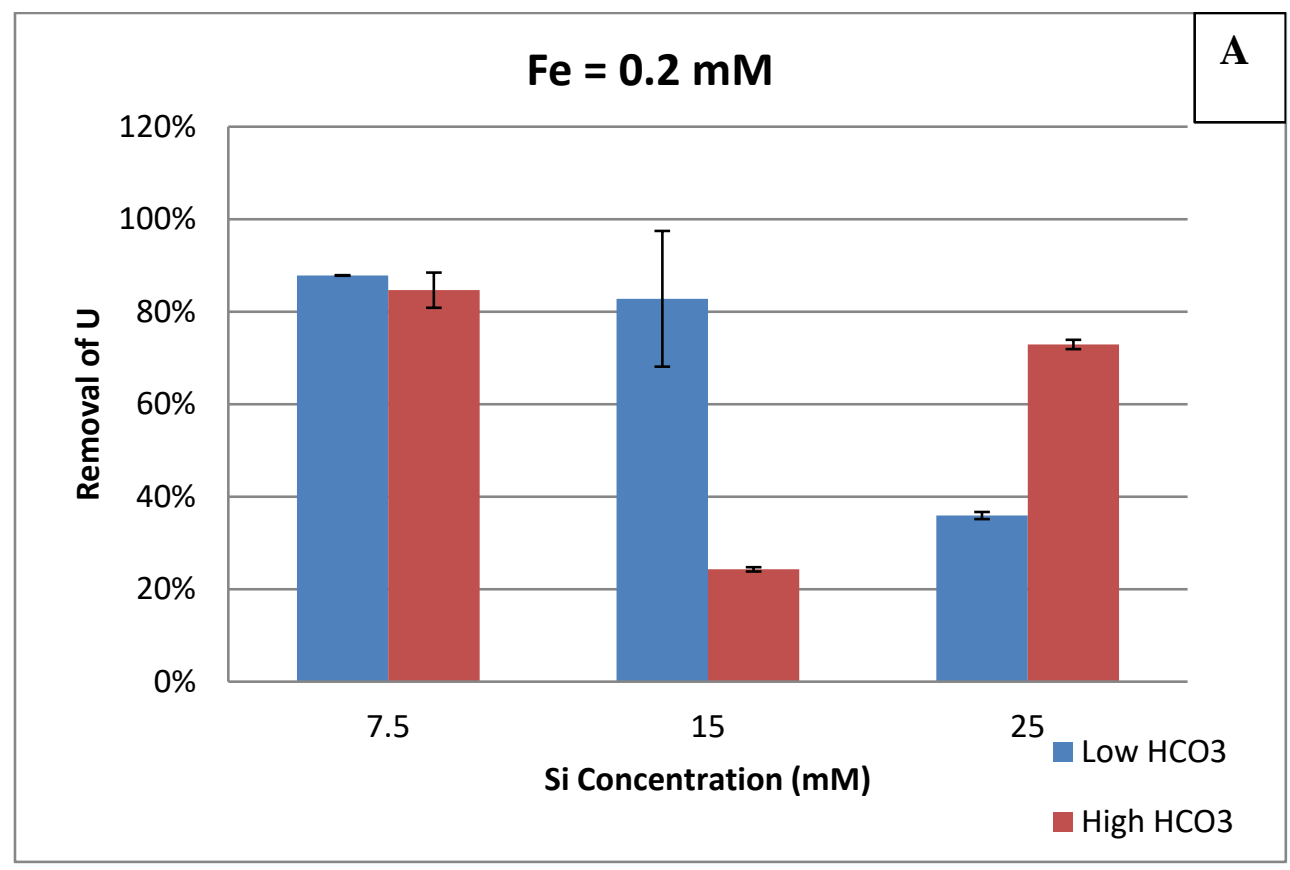




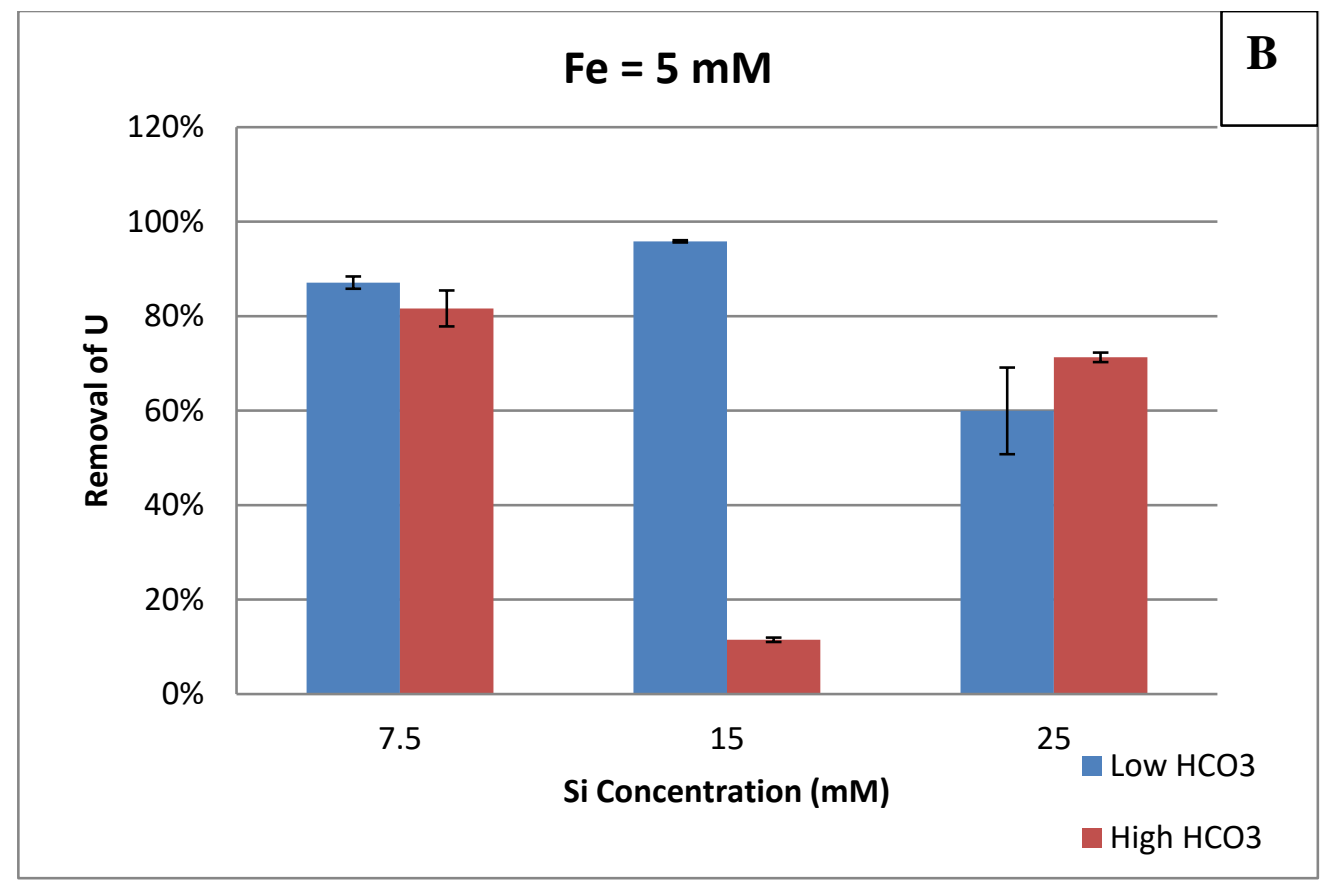

Figure 14: Figure 13: Percent removal of $U$ (VI) tested at variable bicarbonate and silica concentrations in $5 \mathrm{mM}$ Al amended solutions containing $2 \mathrm{mg} / \mathrm{L} \mathrm{U}$ (VI) and (A) $0.2 \mathrm{mM}$; and (B) $5 \mathrm{mM}$ of Fe

The results of $U$ removal in samples containing Fe, showed a relative different trend to those containing $\mathrm{Ca}$ and $\mathrm{Mg}$. In the presence of low bicarbonate concentrations, the removal efficiencies of $U$ tend to be higher caused by possible formations of uranyl carbonates and iron oxides solid phases. Similar to the previous cases, under "high" concentration of bicarbonate, removal efficiencies are lower, which can be attributed to the formation of stable soluble uranyl carbonates.

The main difference was that in the scenario of higher silica concentrations $(25 \mathrm{mM})$, the samples containing high bicarbonate concentrations resulted in higher $U$ removal efficiencies compared to their low bicarbonate counterparts. This suggests that high silica concentrations might play a role in the removal of $U$ in the presence of Iron, possibly forming greater precipitation of iron oxides leading to co-precipitation of $U$ or reducing the formation of soluble and stable uranyl carbonates species. 


\section{CONCLUSIONS}

The results from the sequential extraction experiment provides evidence to suggest that $\mathrm{U}$ present in the solid particles has strong bonds to sediments located in the vadose zone, causing the precipitates created after ammonia $\left(\mathrm{NH}_{3}\right)$ gas injections to be stable and therefore the remediation technology to be effective under the simulated conditions. Furthermore, evidence shows that there were little soluble $\mathrm{U}$ phases found in solutions after $\mathrm{NH}_{3}$ gas treatment. This finding is of great importance given these $\mathrm{U}$ phases are of the greatest concern in terms of further contamination potential caused by migration to groundwater or the surrounding water resources in the Hanford Site.

Additionally, the results obtained from the low Si experiment, provide details on the effect of different low Si concentrations on the removal/precipitation efficiency of U (VI). From the experiment, it is evident that solutions with higher concentrations of Si tended to have generally greater removal efficiencies of $\mathrm{U}(\mathrm{VI})$. The highest percent removal of $\mathrm{U}(\mathrm{VI})$, $98-99 \%$, was achieved at Si concentration of $25 \mathrm{mM}$ in the solutions containing calcium and bicarbonate concentrations of $10 \mathrm{mM}$ and $3 \mathrm{mM}$, respectively, possibly explained by the formation of stable solid uranyl silicates, calcium carbonates and calcium silicates as well as silica polymerization reactions leading to co-precipitation of $U$. The lowest percent removal of $\mathrm{U}(\mathrm{VI}), 2-3 \%$, was observed at low Si concentration of $7.5 \mathrm{mM}$ in the solutions containing high bicarbonate concentration of $50 \mathrm{mM}$, probably favoring the presence of strong soluble uranyl carbonates, suggesting that solutions with higher concentrations of bicarbonate resulted in lower removal efficiencies of $\mathrm{U}(\mathrm{VI})$. 


\section{- Future Work}

Future experiments on stability of U-bearing precipitates via sequential extraction experiment using different silica and bicarbonate concentrations could help understand the variances found in the removal of $\mathrm{U}$ from $\mathrm{NH}_{3}$ gas treated solutions. Additionally, continuous leach extraction experiments consisting of injecting less and more aggressive extractants into small columns containing the U-bearing precipitates and collecting samples overtime would complement the results found in this study by evaluating the relative extractability of $U$ and influence of contact time in $U$ removal efficiencies and $U$ leakage potential. In addition, other major constituents found in the soils at different concentrations such as iron $(\mathrm{Fe})$ combined with high concentrations of Si and bicarbonate could be used to prepare new U-bearing precipitates and evaluate their role in removal efficiency of U (VI). Finally, speciation modeling could be of great support to predict the distribution of uranyl aqueous species and formation of uranium solid phases likely to be present in tested compositions. 


\section{REFERENCES}

Bjornstad B.N, K.R Fecht, and C.J Pluhar. 2001. "Long history of pre-Wisconsin, ice-age, cataclysmic floods: Evidence from southeastern Washington State." Journal of Geology 109:695-713.

Bjornstad, B.N., 1990. Geohydrology of the 218-W-5 burial ground, 200-west area, Hanford site. PNNL-7336, Pacific Northwest National Laboratory, Richland, WA.

Bunn, A. L, et al., 2002. Hanford Site National Environmental Policy Act (NEPA) Characterization. PNNL-6415 Rev. 14 Prepared for the U.S. Department of Energy.

Corbin, R. A., Simpson, B. C., Anderson, M. J., Danielson, W. F. I., Field, J. G., Jones, T. E., \& Kincaid, C. T. (2006). Hanford soil inventory model rev. 1. (User's Guide No. 1). Richland, Washington.: Pacific Northwest National Laboratory. . (RPP-26744, Rev 0, CH2M HILL Hanford Group, Inc.,)

DOE 1988. Site Characterization Plan, Reference Repository Location, Hanford Site, Washington. Vol.1, Consultation Draft. U.S. Department of Energy. Richland, Washington. 1988.

Guillaumont, R., \& Mompean, F. J. (2003). Update on the chemical thermodynamics of uranium, neptunium, plutonium, americium and technetium.

Hartman, M. J., Morasch, L. F., \& Webber, W. D. (2007). Hanford site groundwater monitoring summary for fiscal year 2006. ( No. PNNL-16343). Richland, Washington.: Pacific Northwest National Laboratory.

Iler, R. K. (1979) The chemistry of silica: solubility, polymerization, colloid and surface properties, and biochemistry. Canada: John Wiley \&Sons Inc.

Katsenovich, Y. P., Cardona, C., Lapierre, R., Szecsody, J., \& Lagos, L. E. (2016). The effect of $\mathrm{Si}$ and $\mathrm{Al}$ concentrations on the removal of $\mathrm{U}(\mathrm{VI})$ in the alkaline conditions created by NH 3 gas. Applied Geochemistry, 73, 109-117.

Langmuir, D. (1997). Aqueous environmental chemistry. Upper Addle River New Jersey.: Prentice-Hall, Englewood Cliffs.

Last, G. V. N. Bjornstad, M. P. Bergeron, D. W. Wallace, D. R. Mewcomer, J. A. Schramke, M. A. Chamnes, C. S. Cline, S. P. Airhart, and J. S.Wilbur. 1989. Hydrology of the 200 Areas Low Level Burrial Grounds - An Interim Report. PNNL- 6820 Vol. 1, Pacific Northwest Laboratory, Richland, Washington.

Last, G., Gee, G., Freeman, E., Nichols, W., Cantrell, K., Bjornstad, B., Fayer, J., Horton, D. 2006. Vadose Zone Hydrogeology Data Package for Hanford Assessments. PNNL14702, Rev. 1. Prepared for the U.S. Department of Energy. 
Lindenmeier, C.W., Lindberg, M.J., Geiszler, K.N., Serne, R.J., Clayton, R.E., Brown, C.F., Bjornstad, B.N., LeGore, V.L., Valenta, M.M., Gee, G.W., Kutnyakov, I.V., Vickerman, T.S., Schaef, H.T., Baum, S.R., Royack, L.J., Lanigan. D.C. 2003. Characterization of Vadose Zone Sediment: RCRA Borehole 299-E33-338 Located Near the B-BX-BY Waste Management Area. PNNL-14121. Prepared for the U.S. Department of Energy.

Qafoku, N. P., Ainsworth, C. C., Szecsody, J. E., \& Qafoku, O. S. (2004). Transportcontrolled kinetics of dissolution and precipitation in the sediments under alkaline and saline conditions. Geochimica Et Cosmochimica Acta, 68(14), 2981-2995.

Serne, R. J., Bjornstad, B. N., Schaef, H. T., Williams, B. A., Lanigan, D. C., Horton, D. G., ... \& Brown, C. F. (2002). Characterization of vadosue zone sediment: Uncontaminated RCRA borehole core samples and composite samples.

Serne RJ, Mitroshkov AV, Serne JN, Bjornstad BN, LeGore VL, Last GV, Schaef HT, O'Hara, MJ, Smith SC, Williams BA, Brown CF, Lindenmeier CW, Lanigan, DC, Parker, KE, Zachara, JM, Horton DG, Kutnyakov IV, Burke DS, Clayton, RE, 2008b. Characterization of Vadose Zone Sediment: Uncontaminated RCRA Borehole Core Samples and composite samples. PNNL-13757-1, rev. 1. Prepared for the U.S. Department of Energy.

Serne, R. J., Last, G. V., Gee, G. W., Schaef, H. T., Lanigan, D. C., Lindenmeier, C. W., Orr, R. D. (2008). Characterization of Vadose Zone Sediment: Borehole 299-E33-45 Near BX-102 in the B-BX-BY Waste Management Area,

Simpson, B. C., Corbin, R. A., Anderson, M. J., Kincaid. C. T., 2006. Hanford Soil Inventory Model (SIM) Rev. 1 Software Documentation - Requirements, Design, and Limitations. PNNL-16098. Prepared for the U.S. Department of Energy.

Smith, S. C., \& Szecsody, J. E. (2011). Influence of contact time on the extraction of uranyl spike and contaminant uranium from hanford site sediment. Radiochimica Acta, 99(11), 693; 693-704; 704.

Szecsody, J. E. (2015). Remediation of technetium in vadose zone sediments using ammonia and hydrogen sulfide gases. Vadose Zone Journal, 14(7), 0; 0.

Szecsody, J. E., Truex, M. J., Zhong, L., Johnson, T. C., Qafoku, N. P., Williams, M. D., Faurie, D. K. (2012). Geochemical and geophysical changes during ammonia gas treatment of vadose zone sediments for uranium remediation. Soil Science Society of America, 11(4) doi:10.2136/vzj2011.0158

Szecsody, J. E., Truex, M. J., Zhong, L., Qafoku, N., Williams, M. D., McKinley, J. P., ... \& Phillips, J. L. (2010). Remediation of Uranium in the Hanford Vadose Zone Using Ammonia Gas: FY 2010 Laboratory-Scale Experiments (No. PNNL-20004). Pacific 
Northwest National Laboratory (PNNL), Richland, WA (US), Environmental Molecular Sciences Laboratory (EMSL).

US DOE, Standardized stratigraphic nomenclature for Post-Ringold Formation Sediments within the Central Pasco Basin. Department of Energy, Richland Operations, Richland, Wa., DOE/RL-2002-39, 2002

US, DOE. Environmental Assessment for the Transfer of 1100 Area, Southern Rail Connection and Rolling Stock, Handford Site, Richarland, Washington, 1998. DOE/EA1260 report

Xie Y., Last, G.V., Murray, C.J., Mackley. R. 2003. Mineralogical and Bulk-Rock Geochemical Signatures of Ringold and Hanford Formation Sediments. PNNL-14202. Prepared for the U.S. Department of Energy.

Zachara, J. M., Brown, C. F., Christensen, J. N., Davis, J. A., Dresel, P. E., Liu, C., Um, W. (2007). A site wide perspective on uranium geochemistry at the hanford site. (Technical Report No. PNNL-17031 4597; 830403000; TRN: US0807378). Washington, D.C. : United States. Dept. of Energy. ; Oak Ridge, Tenn.: Office of Scientific and Technical Information, U.S. Dept. of Energy, 2007.

Zachara, J. M., Brown, C. F., Christensen, J. N., Davis, J. A., Dresel, P. E., Liu, C., Um, W. (2007). A site wide perspective on uranium geochemistry at the Hanford Site. (Technical Report No. PNNL-17031 4597; 830403000; TRN: US0807378). Washington, D.C. : United States. Dept. of Energy. ; Oak Ridge, Tenn.: Office of Scientific and Technical Information, U.S. Dept. of Energy, 2007.

Zhong, L., Szecsody, J. E., Truex, M. J., Williams, M. D., \& Liu, Y. (2015). Ammonia gas transport and reactions in unsaturated sediments: Implications for use as an amendment to immobilize inorganic contaminants. Journal of Hazardous Materials, 289, 118-129. 